\title{
Amazonian scorpions and scorpionism: integrating toxinological, clinical, and phylogenetic data to combat a human health crisis in the world's most diverse rainforest
}

\author{
Adolfo Borges ${ }^{1,2^{*}}$ (1), Matthew R. Graham ${ }^{3}$, Denise M. Cândido ${ }^{4}$, Pedro P. O. Pardal ${ }^{5}$ \\ ${ }^{1}$ Center for the Development of Scientific Research (CEDIC), Asunción, Paraguay. \\ ${ }^{2}$ Laboratory of Molecular Biology of Toxins and Receptors, Institute of Experimental Medicine, School of Medicine, Central University of Venezuela, Caracas, \\ Venezuela. \\ ${ }^{3}$ Department of Biology, Eastern Connecticut State University, Willimantic, CT, United States. \\ ${ }^{4}$ Laboratory of Arthropods, Butantan Institute, São Paulo, SP, Brazil. \\ ${ }^{5}$ Laboratory of Medical Entomology and Venomous Animals, Center of Tropical Medicine, Federal University of Pará (UFPA), Belém, PA, Brazil.
}

\section{Keywords:}

Amazonia

Scorpionism

Scorpion antivenom

Tityus

\begin{abstract}
Venom from Amazonian scorpions of the genus Tityus contains components capable of eliciting a distinct clinical, mostly neurological, syndrome. This contrasts with the mainly autonomic manifestations produced after envenomation by congeneric southern and northern South American species. Herein, we summarize Pan-Amazonian scorpionism by synthesizing available toxinological, clinical, and molecular data gathered from all affected areas in Amazonia, including Brazil, Ecuador, Colombia, Peru, Venezuela, and French Guiana. We searched multiple databases, as well as our own records, for reports of scorpion envenomations in Amazonia by confirmed Tityus spp., and compared the clinical manifestations. To help uncover clinical and venom relationships among problematic species, we explored phylogenetic relationships with a rate-calibrated analysis of mitochondrial COI data from available species. The possible existence of diversity gradients for venom toxic and immunogenic components despite the predicted strong phylogenetic association among species is underscored by discussed clinical and toxinological findings. A multicentric effort, involving all nations affected by this neglected disease, is urgently needed to offer alternatives for treating and understanding this pathology, including the preparation of neutralizing antibodies with a broad range of efficacy.
\end{abstract}

* Correspondence: borges.adolfo@gmail.com https://doi.org/10.1590/1678-9199-JVATITD-2021-0028 Received: 11 March 2021; Accepted: 21 May 2021; Published online: 29 November 2021 


\section{Background}

Scorpionism, or the medical consequence of scorpion stings in humans, is a neglected health problem in tropical and subtropical areas associated with poverty and the lack of access to effective antivenoms. Rapid tissue distribution of scorpion toxins targeting specific ion channels associated with excitable and immunological cells usually results in high mortality rates in children under 10 years of age. As such, severe stings require prompt treatment with specific antivenoms and intensive cardiorespiratory support [1]. In the Americas, Mexico has the highest scorpion envenomation incidence [2], followed by the Amazon region where the rate has been estimated to range between 30 and 200 cases per 100,000 inhabitants [3]. These numbers are most probably an underestimation as large sections of Amazonia remain epidemiologically underreported, with the number of cases to be much higher in remote riverine and indigenous communities [3-5].

Tityus represents a diverse group of buthid scorpions primarily distributed throughout South America, Central America, and the Caribbean. Species of the genus are responsible for the majority of severe envenomation cases throughout South America, especially the Amazon region, where it reaches its highest species diversity [5, 6]. Analyses of Tityus envenomations throughout Amazonia, mainly Brazil, have revealed neurological manifestations that sharply contrast with the mainly peripheral manifestations elicited by congeneric species from northern and southeastern South America [6]. Thus, Amazonian Tityus contain venoms with unique physiopathological mechanisms.

Significant efforts have been made to understand and treat scorpionism in Amazonia, particularly along the Brazilian Amazon River Basin $[4,7,8]$. In this region, a pattern of increased scorpion sting incidence is notable from 2000 to 2017, especially in the states of Pará, Tocantins, Maranhão and Mato Grosso. Lethality from stings in these areas is significantly higher compared to other regions of Brazil, probably due to a lack of experienced health personnel, appropriate antivenom-based therapies, and an overall lower quality of care in rural towns [5]. A research consortium "Snakebite and Scorpionism Network in the Amazon" has emerged as a joint effort from scientists at the Butantan Institute and the Tropical Medicine Foundation, in Manaus, to understand and combat the problem in Brazil [4]. However, a similar pathology occurs in other regions of the Amazon Basin as well. Specifically, severe cases and fatalities have been reported from French Guiana, Venezuela, Guyana, Colombia, Ecuador, and Peru [9-16].

Amazonia is a mosaic of eight areas of endemism (Figure 1), which share ecologically similar characteristics, but delineated by the distributions of co-distributed taxa, including scorpions [17-20]. Our understanding of scorpionism in this region would undeniably benefit from a comparative analysis of data on the distributions of medically significant species (Tityus spp.), envenomation physiopathology, and toxinology. Additionally, relationships among Amazonian Tityus and their venoms could be improved by molecular phylogenetic analyses.
About 65\% of Amazonia lies within Brazil, but only four areas of endemism are almost entirely (Rondônia) or entirely (Tapajós, Xingu, and Belém) Brazilian. Less than $50 \%$ of the Napo and Imeri areas are in Brazil, and the scorpion envenomation problem is increasing in sections of these areas in Colombia, Ecuador and Peru $[14,16]$ (see also https://web.ins.gob.pe/index.php/ es/prensa/noticia/instituto-nacional-de-salud-traslado-sueroantiescorpionico-para-nino-de-comunidad).

Recently, a phylogeny generated with mitochondrial markers revealed that $T$. cisandinus from Amazonian Ecuador (Napo area) is closely related to medically significant $T$. obscurus populations from the Brazilian northeast. Thus, species capable of severe envenomations, the putative "Tityus obscurus" species complex, are distributed across the Amazon basin [14], a result corroborated by recent morphological data [20]. A joint effort by scorpion biologists and toxinological/medical teams should help elucidate the actual extent of this and other species complexes in Amazonia. Such an understanding will lay the framework for studies of shared and/or expression of unique venom components, and will aid in the design of better therapeutic tools against scorpionism.

This review integrates clinical and toxinological data on scorpionism and scorpions from the regions of endemism that comprise Amazonia. The territories of Guyana, Surinam, French Guiana, and southeast Venezuela do not belong to the Amazon River Basin, but they share problematic scorpion species with other areas of the Basin. As such, they will be considered as part of Amazonia in this review, providing a Pan-Amazonian perspective on scorpionism. Additionally, relationships among Amazonian Tityus spp. of medical importance are explored within a molecular phylogenetic context. We hope this review encourages further investigation across all countries involved in the search of collective alternatives to study and combat scorpionism across Amazonia.

\section{Towards a working phylogeny of Amazonian Tityus}

About 2\% of the world's arachnids live in Amazonia, and almost $25 \%$ of the arachnid families presently known are represented in this region. Of these, about 200 species are scorpions, comprising about $13 \%$ of the world's scorpion diversity [21]. Despite this diversity, only four of the Neotropical scorpion families are represented in the Amazon: Buthidae, Chactidae, Ischnuridae, and Troglotayosicidae [22]. Of these, Buthidae is by far the most diverse, with most species belonging to the genus Tityus, which cause most severe human envenomations in the region [23]. Clinical data are lacking for the other Amazonian scorpions, suggesting Tityus spp. may be the only regional scorpions for which stings result in more than just local symptomatology. The large and abundant chactid Brotheas amazonicus, for example, is known to invade disturbed areas but is barely toxic to mice [24].

To date, a total of 49 Tityus spp. have been reported from the eight abovementioned areas of endemism (Table 1). These species 
represent $22 \%$ of the known Tityus diversity $(\mathrm{n}=224)$ [25], and inhabit eight Amazonian countries: Colombia, Ecuador, Peru, Venezuela, Guyana, French Guiana, Suriname, and Brazil. A map of the Amazon region depicting approximate distributions for some of these species, superimposed on the reported areas of endemism [17], is provided in Figure 1. The habitus of representative Tityus species are presented in Figure 2, and medically important taxa from Brazilian and Ecuadorean Amazonia are listed in Table 1 (in bold).

After reviewing the distributional data, T. metuendus, T. obscurus, T. silvestris, T. bastosi, T. apiacas, and T. strandi are clearly the most widely distributed species in the Amazon Basin. These are also responsible for the majority of envenomation cases in Brazilian Amazonia [5]. However, most Amazonian Tityus species are only known from their type localities, and little information is currently available on their actual areas of distribution. Data presented in Figure 1 and Table 1 show that Guiana harbors the greatest number of species $(n=36)$, followed by Napo $(n=5)$, Imeri $(n=4)$, Inambari $(n=4)$, Belém $(n=$ $3)$, Tapajós $(n=3)$, Rondônia $(n=2)$, and Xingú $(n=2)$. Large sections of Amazonia, mainly in Inambari and Imeri, remain poorly sampled. More thorough sampling of these areas may result in the discovery of new taxa. Therefore, we suspect that the number of medically important Tityus species across Amazonia, mainly belonging to the subgenus Atreus, is probably higher [23], and additional species, particularly in rainforest areas of Peru and northern Bolivia, are probably yet to be discovered.

The absence of phylogenetic analyses of Tityus species in Amazonia have hindered efforts to understand toxinological relationships among problematic species [30]. Only two phylogenetic analyses of Tityus spp. have been published; one encompassing Venezuelan species [31], and another comprising the southernmost South American species [32]. Assuming that there is some phylogenetic signal to venom toxicity in Tityus (i.e venoms are more similar among closely related species), as indicated by recent studies [33], then phylogenetic data can be used to make predictions regarding the toxicity of species that have yet to be toxinologically assessed.

Divergence time estimates, based on mitochondrial COI (cytochrome oxidase subunit I) data used in DNA barcoding [31], are provided in Figure 3 for 11 medically important Tityus species in South America; this includes samples of Amazonian $T$. obscurus (two populations, from eastern and western Pará, Brazil [14]), T. metuendus (from the Essequibo area in Guyana [34]), and

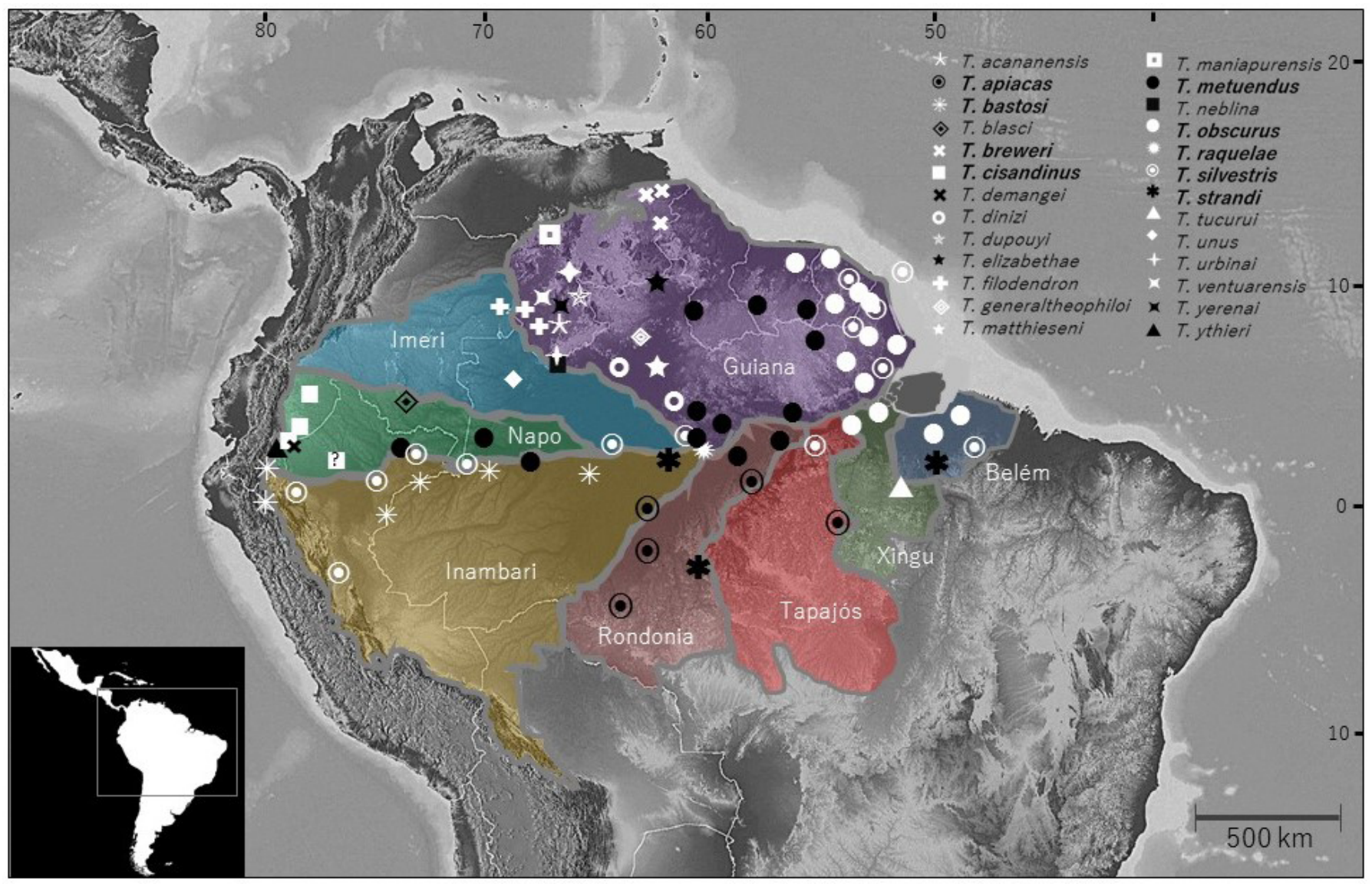

Figure 1. Distribution map of representative Amazonian Tityus species, superimposed on the areas of endemism defined for Amazonia [17]. Distribution areas for Brazilian, Colombian, Ecuadorean, Peruvian, and French Guiana taxa [20, 23, 29, 30, 31, 32, 33] and distribution areas for Venezuelan taxa [27, 28]. T. cisandinus distribution in Peru has been posited but not demonstrated [34]. Species names in boldface correspond to medically important species (see Table 1). 
Table 1. Updated list (as of January 2021) of Amazonian species $(n=49)$ in the genus Tityus and their distribution in Amazonian areas of endemism [17]. Species from Brazilian Amazonia are listed based on Monteiro et al. [5], with updates from Lourenço et al. [20]. Species from French Guiana are listed based on Ythier [26], species from Venezuela are based on Ochoa and Rojas-Runjaic [27] and González-Sponga [28], and records from Colombia according to Lourenço [29]. Species in bold correspond to taxa implicated in reported envenomation cases [5, 15, 14].

Species Distribution Amazonian subregion

Tityus acananensis González-Sponga, 2009

Tityus adisi Lourenço \& Pezier, 2002

Tityus anduzei González-Sponga, 1997

Tityus anori Lourenço, Rossi \& Wilmé, 2019

\section{Tityus apiacas Lourenço, 2002}

Tityus bastosi Lourenço, 1984

\section{Tityus breweri González-Sponga, 1997}

Tityus blanci Lourenço, 1994

Tityus canopensis Lourenço, 2002

Tityus cesarbarrioi González-Sponga, 2001

\section{Tityus cisandinus Lourenço \& Ythier, 2017}

Tityus clathratus C.L. Koch, 1844

Tityus culebrensis González-Sponga, 1994

Tityus demangei Lourenço, 1981

Tityus dinizi Lourenço, 1997

Tityus dupouyi González-Sponga, 1987

Tityus elizabethae Lourenço \& Ramos, 2004

Tityus filodendron González-Sponga, 1981

Tityus gasci Lourenço, 1981

Tityus generaltheophiloi Lourenço, 2017

Tityus grahami Lourenço, 2012

Tityus jussarae Lourenço, 1988

Tityus lokiae Lourenço, 2005

Tityus kukututee Ythier, Chevalier \& Gangadin, 2020

Tityus mana Lourenço, 2012

Tityus manakai González-Sponga, 2004

Tityus maniapurensis González-Sponga, 2009

Tityus matthieseni Pinto-da-Rocha \& Lourenço, 2000

Tityus marajoensis Lourenço \& da Silva, 2007
Acanaña, Alto Orinoco municipality,

Amazonas state, Venezuela

Guiana

Tarumã Mirim, Manaus region, Amazonas state, Brazil

Guiana

Miyayobaweteri, Parima range, Atabapo department, Amazonas state, Venezuela

Guiana

Anori, Amazonas state, Brazil

Northern Mato Grosso, Rondônia, southern Amazonas and Pará states, Brazil

Central and eastern Amazonia, spanning Brazil, Perú, Colombia, and Ecuador

Northeastern Bolívar state, Venezuela; possibly Guyana

Amazonas and Meta departments, Colombia

Tarumã Mirim, Manaus region, Amazonas state, Brazil

Santa Rosa creek, Cuyuní river basin, Bolívar state, Venezuela

Guiana

Inambari, Tapajós, Rondônia

Guiana

Inambari

Napo

Guiana

Guiana

Morona Santiago and Pastaza provinces, Ecuador; possibly Loreto department, Perú

Napo

Roraima state, Brazil; Guyana

Guiana

Culebra, Atabapo department, Amazonas state, Venezuela

Los Tayos cave, Morona Santiago province, Ecuador Amazonas state, Brazil

Guiana

Napo

Guiana

Simarawochi, Atabapo department,

Amazonas state, Venezuela

Guiana

Marco Brasil Venezuela Nº, Pacaraima, Roraima state, Brazil

Guiana

Río Negro department, Amazonas state, Venezuela; Guainía department, Colombia

Guiana, Imeri

French Guiana; Amazonas and Roraima states, Brazil; Perú

Guiana

Serra da Mocidade, Roraima state, Brazil

Guiana

Barcelos, Upper Rio Negro, Amazonas state, Brazil

Guiana

Alto Lagarto cave, Napo province, Ecuador

Napo

Amazonas state, Brazil

Guiana

Guiana

Pierre Kondre, near Carolina, Para District, Suriname

Guiana

Central and northeastern French Guiana

Guiana

Manaka, Atabapo municipality,

Amazonas state, Venezuela

Los Colorados, Cedeño municipality,

Bolívar state, Venezuela

Guiana

Roraima state, Brazil

Guiana

Pará state, Brazil
Belém 
Table 1. Cont.

\begin{tabular}{|c|c|c|}
\hline Species & Distribution & Amazonian subregion \\
\hline Tityus metuendus Pocock, 1897 & $\begin{array}{l}\text { Amapá, Pará, Roraima, and Amazonas states, } \\
\text { Brazil; Loreto department, Perú; Sipaliwini District, } \\
\text { Suriname; Rupununi River next to Lethem, Guyana }\end{array}$ & $\begin{array}{l}\text { Guiana, Rondônia, } \\
\text { Inambari, Napo }\end{array}$ \\
\hline Tityus neblina Lourenço, 2008 & Neblina Peak, border between Brazil and Venezuela & Guiana \\
\hline Tityus nelsoni Lourenço, 2005 & $\begin{array}{l}\text { São Gabriel da Cachoeira, Río Negro region, } \\
\text { Amazonas state, Brazil }\end{array}$ & Imeri \\
\hline Tityus obscurus (Gervais, 1843) & $\begin{array}{l}\text { Amapá and Pará states, Brazil; } \\
\text { widespread in French Guiana; Suriname }\end{array}$ & Guiana, Belém, Tapajós. Xingú \\
\hline Tityus raquelae Lourenço, 1988 & Amazonas state, Brazil & Guiana \\
\hline Tityus riocaurensis González-Sponga, 1996 & $\begin{array}{c}\text { Tabaro River, Rio Caura Forest Reserve, } \\
\text { Cedeño municipality, Bolívar state, Venezuela }\end{array}$ & Guiana \\
\hline Tityus rionegrensis Lourenço, 2006 & Amazonas state, Brazil & Guiana \\
\hline Tityus sarisarinamensis González-Sponga, 2002 & $\begin{array}{l}\text { Jaua-Sarisariñama National Park, } \\
\text { Sucre municipality, Bolívar state, Venezuela }\end{array}$ & Guiana \\
\hline Tityus romeroi González-Sponga, 2008 & El Palmar, Imataca range, Bolívar state, Venezuela & Guiana \\
\hline Tityus shiriana González-Sponga, 1991 & $\begin{array}{l}\text { Neblina Peak, Río Negro department, } \\
\text { Amazonas state, Venezuela }\end{array}$ & Guiana \\
\hline Tityus silvestris Pocock, 1897 & $\begin{array}{l}\text { Widespread along the Amazon basin } \\
\text { spanning Brazil, Ecuador, and Perú }\end{array}$ & $\begin{array}{l}\text { Guiana, Belém, Tapajós. } \\
\text { Inambari, Napo }\end{array}$ \\
\hline Tityus strandi Werner, 1939 & $\begin{array}{l}\text { Pará and Amazonas states, Brazil, } \\
\text { along the Amazon and Solimões river basins }\end{array}$ & Belém, Inambari \\
\hline Tityus sylviae Lourenço, 2005 & $\begin{array}{c}\text { PNJ Seringalzinho, Río Negro region, } \\
\text { Amazonas state, Brazil }\end{array}$ & Imeri \\
\hline Tityus tucurui Lourenço, 1988 & Cenral and eastern Pará state, Brazil & Imeri \\
\hline Tityus unus Pinto-da-Rocha \& Lourenço, 1984 & Tapurucuara, Amazonas state, Brazil & Xingú \\
\hline Tityus urbinai (Scorza, 1954) & $\begin{array}{l}\text { Mawari-Anejidi, Atabapo department, } \\
\text { Amazonas state, Venezuela }\end{array}$ & Guiana \\
\hline Tityus venamensis González-Sponga, 1981 & Venamo Hill, Roscio district, Bolívar state, Venezuela & Guiana \\
\hline Tityus ventuarensis González-Sponga, 2009 & $\begin{array}{c}\text { Juanaña, border between Atures and Atabapo } \\
\text { municipalities, Amazonas state, Venezuela }\end{array}$ & Guiana \\
\hline Tityus yerenai González-Sponga, 2009 & $\begin{array}{c}\text { Caño Iguana, Manapiare municipality, } \\
\text { Amazonas state, Venezuela }\end{array}$ & Guiana \\
\hline Tityus ythieri Lourenço, 1988 & South of Yaupi, Morona Santiago province, Ecuador & Napo \\
\hline
\end{tabular}

T. cisandinus (from Morona Santiago, Ecuador [14]). Sequences for these species, as well as two outgroup samples (Centruroides infamatus and C. noxius) were retrieved from GenBank and aligned in Geneious v.7.1.7 (Biomatters Ltd., Auckland, New Zealand) using MUSCLE [35]. We estimated the best-fit substitution model with MEGA X [36] and conducted a Bayesian analysis in BEAST 1.8.0 [37]. We performed two independent MCMC runs for 40 million generations each and sampled every 4,000 generations, with a uncorrelated lognormal clock model, Yule tree prior, and mean rate (ucld.mean) adjusted according to clock calibrations used in previous analyses of Tityus scorpions [32].

The Bayesian analysis identified two major groups within Tityus: a clade comprising southern South American species (T. serrulatus and T. trivittatus populations from Paraguay and Argentina), and a second group incorporating species from Lower Central America (T. asthenes), northern South America
(T. discrepans, T. zulianus, T. perijanensis), and Amazonian species T.obscurus, T. metuendus, and T. cisandinus. Interestingly, the three Amazonian species were rendered as monophyletic with strong support. The two main clades have been reported in previous studies [31,32], but ours is the first to document the common ancestry of Amazonian Tityus.

Although node support was not strong, our phylogenetic analyses suggest that the Colombian/Venezuelan T. perijanensis is sister to the Amazonian species (Figure 3). This association is supported by data on T. perijanensis envenomation syndrome (e.g presence of neurological manifestations in envenomed humans such as tonic-clonic convulsions and neurogenic bladder) and toxinology (e.g sharing of toxin homologs with the Amazonian group) $[33,38]$. Divergence time estimates indicate that the Amazonian populations probably shared a common ancestor between the early and late Miocene, with a middle Miocene mean 

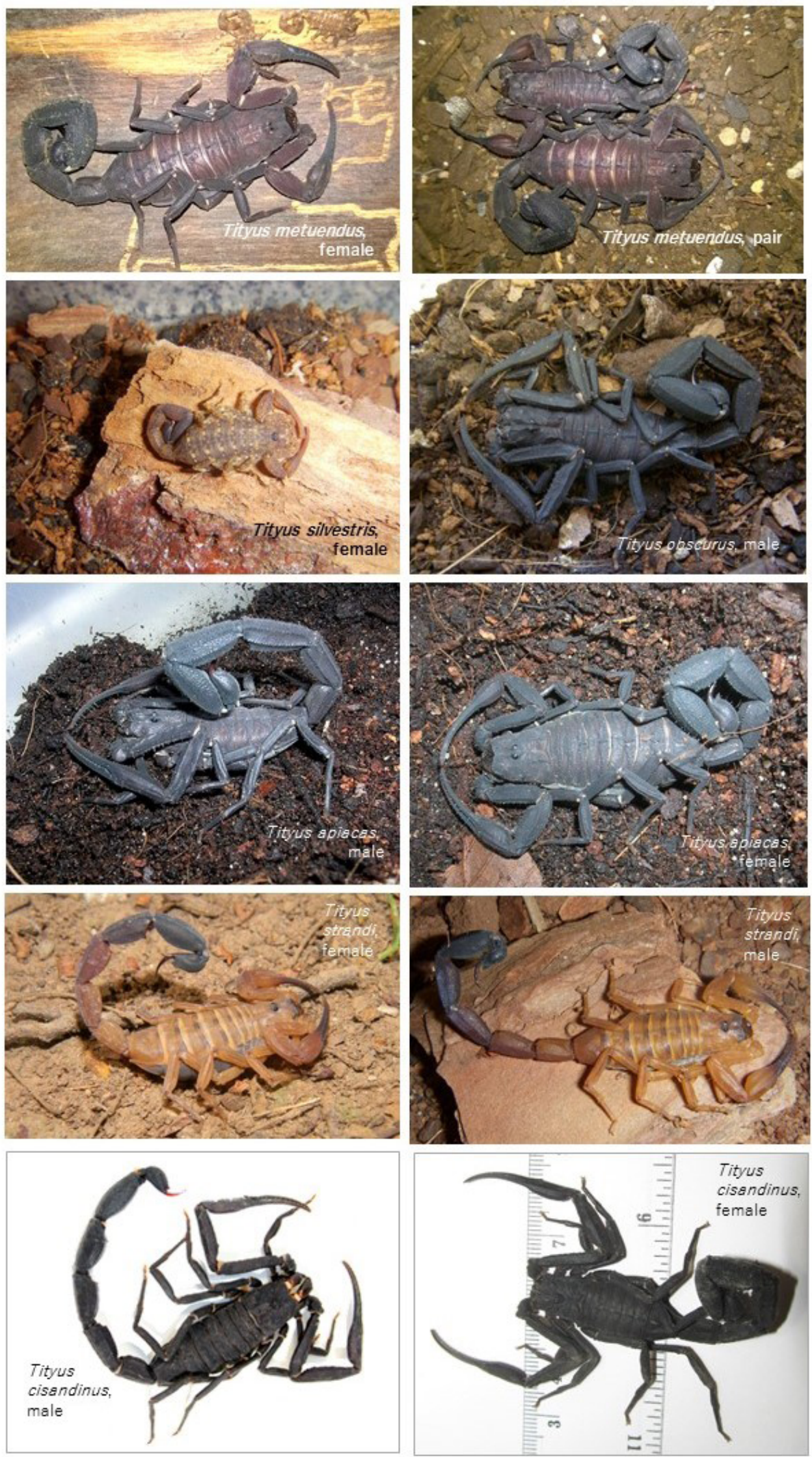

Figure 2. Representative Tityus species from Brazilian and Ecuadorean Amazonia. Photographs of Brazilian specimens by Denise Cândido, and those of $T$. cisandinus by Adolfo Borges. 


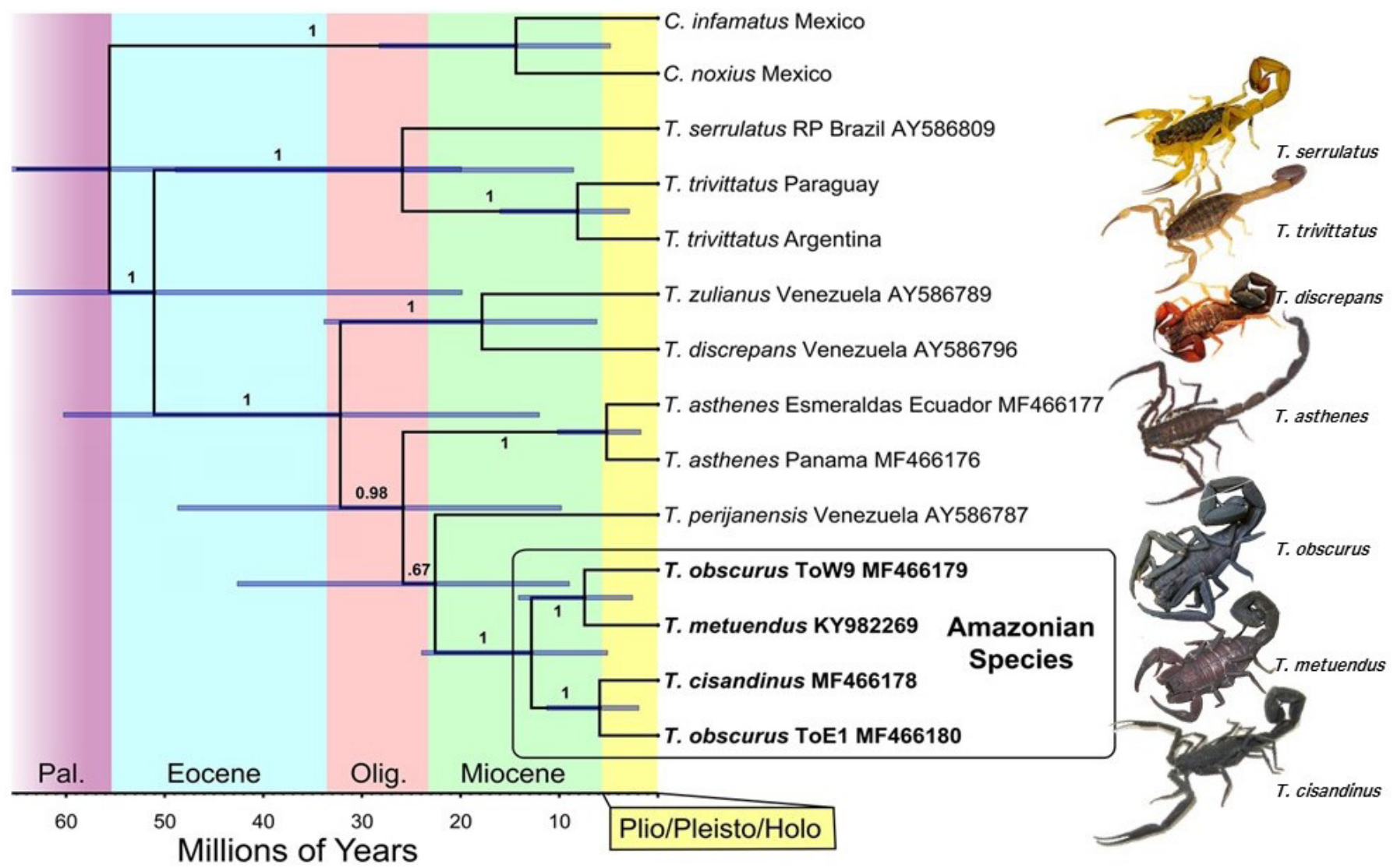

Figure 3. Bayesian chronogram of medically significant Tityus spp. in South America, generated in BEAST. Values at nodes indicate posterior probabilities; bars indicate highest posterior density (HPD) values around mean date estimates. GenBank accession numbers are provided in the tip labels. Centruroides infamatus and C. noxius (Buthidae) were included as an outgroup. Samples of T. obscurus ToW9 and ToE1 come from western and eastern Pará, Brazil, respectively.

estimate of approximately $13 \mathrm{Ma}$. Subsequent diversification among our samples is estimated to have occurred during the late Miocene and Pliocene. An examination of pairwise distance values, uncorrected and KTP corrected (Additional file 1), supports the distinction of the Amazonian samples, as nucleotide diversity is significantly less among them than among the non-Amazonian Tityus species ( $t$-test $\mathrm{p}<0.001$ ).

Considering the closer relationships among the Amazonian Tityus species, despite their wide distribution (see T. obscurus and T. metuendus in Figure 1), we predict that other species that are morphologically similar may be members of the clade as well; particularly T. apiacas, T. dinizi, and T. tucurui [20]. The inclusion of T. cisandinus from Ecuador as a member of the Amazonian clade was recently demonstrated by our team [14].

Results from current analysis together with venom studies on Tityus spp. [33], indicate that species from Lower Central America, Colombia, and the Amazonian regions of Brazil, Ecuador, Peru, and French Guiana, might share enough molecular and toxinological similarities to justify preparation of a scorpion antivenom that should neutralize common venom toxic components. Venom gland transcriptomic data from medically important Amazonian scorpions could confirm this prediction, as the availability of toxin primary structures, deduced from their corresponding cDNAs, should enable toxin comparisons between species and the mapping of antigenic epitopes, as in the case of Tityus serrulatus [39]. Of the Amazonian species of medical importance, the phylogenetic position of T. silvestris would be of particular interest. The species is currently classified in subgenus Archaeotityus [40], which comprises small (18$40 \mathrm{~mm}$ ), variegated scorpions, known to be of little medical significance outside of Amazonia [41]. Within the Amazon River Basin, however, T. silvestris has caused serious envenomations in Brazil, with presentation of neurological manifestations (see section 3). Molecular phylogenetic analyses of other scorpions in subgenus Archeotityus have grouped them in a clade that is sister to southern South American Tityus [32, 31]. Interestingly, T. clathratus, the type species of this subgenus, produces neurotoxins that are structurally related to $\beta$-toxins targeting sodium channels from congeneric southern South America species of medical significance [41]. 


\section{Medical importance of Amazonian Tityus spp.: clinical manifestations and implications associated with envenomation by accurately identified species}

Tackling the scorpionism problem in Amazonia, particularly in the case of toxic Tityus fauna, relies on the identification of specimens associated with envenomations and the correct geographical delimitation of high-risk areas. Secondly, this approach should help uncover shared/differential clinical trends among toxic species, which is essential to the design of new therapeutic tools like the manufacture of a scorpion antivenom effective throughout Amazonia. Ideally, appropriate therapeutic measures should be based on the accurate identification of scorpions responsible for stings, as the envenomation syndrome is dependent on the species. This has been demonstrated with Tityus spp. from Amazonian (predominant neurological manifestations) versus southeastern South American (predominantly peripheral manifestations) species, and also in the case of envenomation by the Venezuelan T. discrepans (mainly gastrointestinal alterations) and T. zulianus (mainly cardiorespiratory manifestations) [6].

Historically, insufficient efforts have been made to accurately identify Tityus spp. implicated in medically significant envenomations [23]. Fortunately, physicians have recently started working with scorpion biologists to identify taxa associated with such incidents $[8,14,30,42,43,44,45,46]$. This is an important approach, as we now understand that the composition and physiological activity of Tityus venoms vary substantially across the geographic distribution of the genus [33, 47, 48]. This result is not surprising, however, given the evolutionary complexity of the genus, the most diverse of all scorpion genera [25].

Given the complexity of Amazonian Tityus, we decided to assess published reports on envenoming syndromes in the region that accurately identified the scorpion as a Tityus spp. following the methodology suggested by PRISMA guidelines [49]. We searched Medline, Scopus, ISI Web of Knowledge, LILACS, and SciELO; the query argument was "Amazonian AND Tityus AND Scorpion AND (Sting OR Envenomation)". Searches retrieved records from 1950 to 2020, including additional documents identified by searching bibliographies of the retrieved studies and in the authors' records. This search strategy aimed at recovering documents clinically describing envenomation cases in Amazonia where the responsible scorpion species was taxonomically identified as a Tityus sp. Only documents confirming the species identity of scorpions responsible for envenomations were included in the full review process. Reports of envenomation cases where the scorpion species was not identified, or was presumably Tityus sp., were either excluded or used only for the discussion. Inclusion and exclusion of documents was assessed independently by two of the authors, and discrepancies were resolved by consensus. Database searches retrieved 777 candidate documents; elimination of duplicates yielded 583 unique records in English, Spanish, or Portuguese. Assessment of titles, abstracts and texts, and the evaluation of documents against inclusion criteria identified 14 reports for full data extraction $[8,11,12,14,15,30,43,44,45,46,50,51,52,53]$. Figure 4 presents the flow diagram of the above review process.

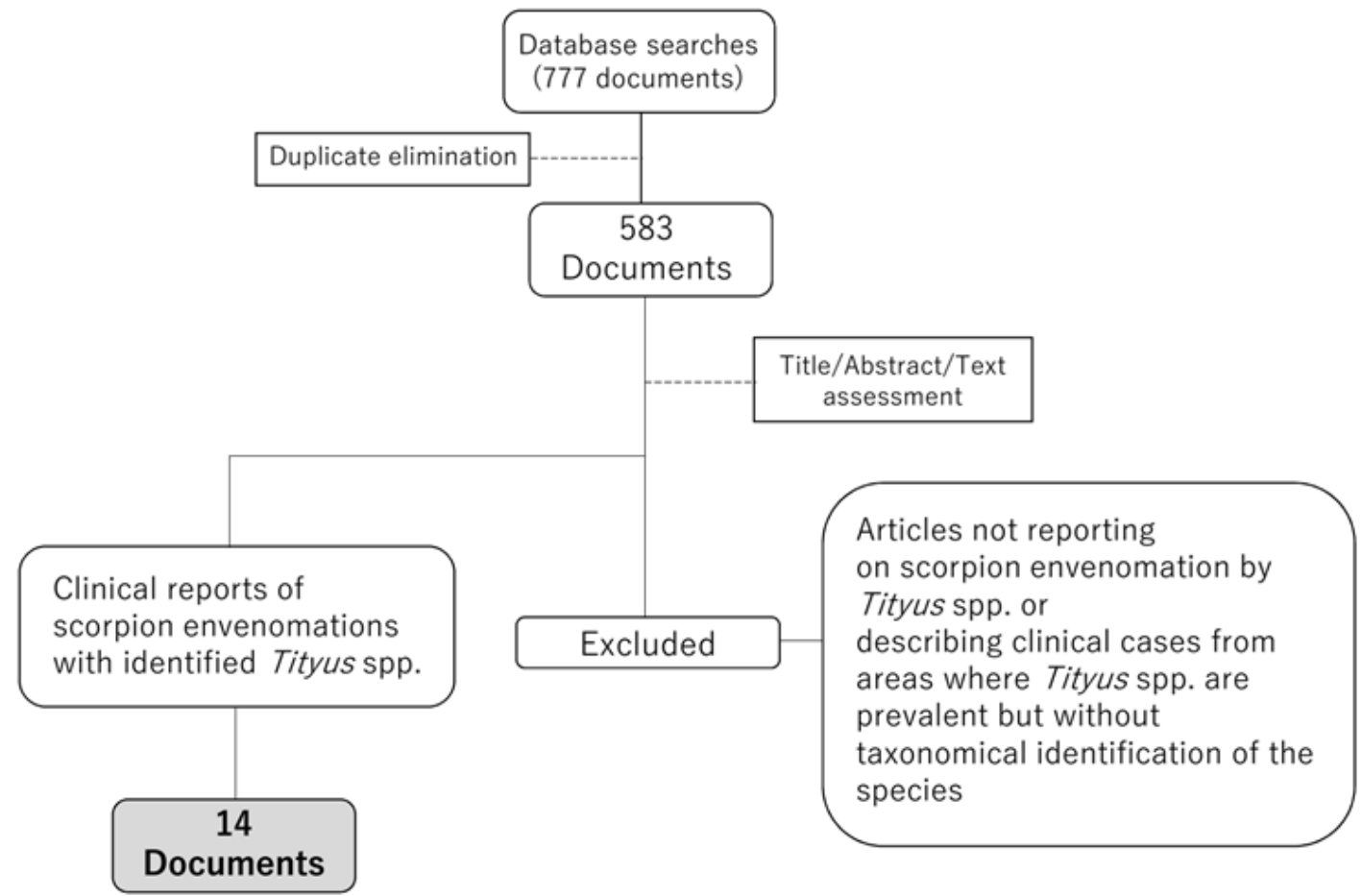

Figure 4. Flow diagram of the review for selecting reports on scorpion envenomation cases from Amazonia caused by taxonomically confirmed Tityus spp. for further analysis of clinical manifestations. 
Clinical manifestations from the abovementioned reports are summarized in Table 2. Envenomation syndromes were reported from the Amazon regions of Brazil, Ecuador, Venezuela, and French Guiana, for a total of 368 envenomation cases during the period 1950 to 2020 . Seven papers analyzed clinical manifestations after envenomation by Tityus obscurus [11, 12, 46, 50, 51, 52, 53] (from Pará state, Brazil, and Cayenne, French Guiana), three by T. silvestris (Pará and Amazonas states, Brazil) $[8,44,45]$, two by T. apiacas (Amazonas state, Brazil) [8, 43], and one each by T. metuendus (Amazonas state, Brazil) [8], T. raquelae (Amazonas state, Brazil) [8], T. strandi (Pará state, Brazil) [30], T. breweri (Bolívar state, Venezuela) [15], and T. cisandinus (from Morona Santiago, Ecuador) [14]. Scorpions involved in human injuries from Amazonian Ecuador reported by Roman et al. [14] which were not identified at that time, but were recently identified by one of the authors as Tityus cisandinus [54].

Local clinical manifestations (at the sting site) occurred in $88.8 \%$ of the cases, with pain and edema being the most frequent. $61.1 \%$ of the cases presented with systemic clinical manifestations, including cardiorespiratory (61.1\%), general, gastrointestinal, and neurological (55.5\%), and ophthalmological alterations (16.6\%). Among the general manifestations, most frequent signs and symptoms were sweating and tremors. Main gastrointestinal manifestations were vomiting, nausea, and sialorrhea. Cardiorespiratory alterations included tachycardia and tachypnea. Ophthalmological manifestations included blurred vision and visual hallucination. Neurological alterations included agitation, somnolence, and myoclonus.

Regarding severity (based on the international consensus scale for classification of scorpion sting severity) [55], 52\% (n $=10$ cases $)$ corresponded to Class I, $40.7 \%(n=13)$ to Class II, $6.7 \%(\mathrm{n}=8)$ to Class III, and $0.5 \%(\mathrm{n}=2)$ to Class IV, which refer to fatal outcomes caused by Tityus obscurus in French Guiana and T. cisandinus in Ecuador.

Stings by $T$. raquelae did not present with systemic manifestations and therefore envenomation by this species is classified as Class I. On the contrary, stings by the remaining analyzed Tityus spp., including taxa from outside the Brazilian Amazonia, presented with systemic manifestations and severities in Classes I to IV, predominantly including neurological complications. In the case of $T$. obscurus, most frequent alterations were somnolence, agitation, myoclonus, dysarthria, "electric shock" sensation, dysmetria, and gait ataxia. In at least one T. obscurus case, generalized myoclonus persisted for more than 3 days, and was refractory to the use of diazepam [53]. In a sting case by T. apiacas, myoclonus was the main manifestation, whereas the primary symptoms after a sting by T. silvestris were headache, agitation, and myoclonus. T. strandi stings mainly produced an "electric shock" sensation and gait ataxia. Summarizing shared and species-specific manifestations, myoclonus have been described for T. obscurus, T. apiacas, and T. silvestris; dysmetria and Romberg signal has only been described in the case of T. obscurus, whereas dysarthria has been reported after envenomation by T. obscurus and T. cisandinus; gait ataxia for T. obscurus and T. silvestris. The "electric shock" sensation has been reported for T. obscurus and T. strandi.

Autonomic (sympathetic and parasympathetic) manifestations, instead of neurological, are predominant after envenomation by southern South America Tityus, such as T. serrulatus and $T$. trivittatus [56, 57], and also by northern Venezuelan scorpions T. discrepans and T. zulianus [58], Colombian Tityus pachyurus and T. asthenes [59, 60], and Trinidadian T. trinitatis [61]. While clinical consequences of peripheral neurotransmitter exacerbation have also been observed after envenomation by Amazonian scorpions, such as T. obscurus (e.g. pancreatitis [12]), neurological complications as seen in these cases are uncommon in South America outside of Amazonia. These alterations are more typical of the envenomation by North American Centruroides spp. $[62,63]$ and South African Parabuthus spp., particularly $P$. transvaalicus [64].

Our analysis underscores the fact that neurological manifestations are present in cases throughout the Amazon region and not just in Brazil, which may underlie common physio-pathological mechanisms among toxins produced by Amazonian Tityus spp. For instance, Folch et al. [50] were first to record in 1950 the "electric shock" sensation in a patient stung by T. cambridgei (later synomyzed with T. obscurus) in French Guiana. Although not included in our analysis (the scorpion was not identified), reports on another scorpion envenomation from French Guiana indicate that it presented with right hemiparesthesia and neurogenic bladder, the latter possibly a result of the onset of a conus medullaris syndrome [65]. Neurological manifestations, including tonic-clonic convulsions, have also been reported after scorpion stings in areas inhabited by $T$. perijanensis [38], a species inhabiting the Colombia/ Venezuela border, which has been shown to produce sodium channel-active toxins structurally related to toxins from $T$. obscurus and T. metuendus [33]. Muscle fasciculations were recorded after T. breweri envenomation in Amazonian Venezuela, and by a Tityus spp. in Huila, southern Colombia (Imeri area of endemism), which is a manifestation not usually observed after stings by Tityus spp. in those countries, and is reminiscent of similar effects in the case of T. obscurus $[15,16]$ (Table 2). 
Table 2. Scorpion envenomation cases recorded in the Amazon region with positively identified associated species in the genus Tityus in the period from 1950 to 2020.

\begin{tabular}{|c|c|c|c|c|c|c|c|c|c|c|c|c|c|c|c|c|c|c|}
\hline $\begin{array}{l}\text { Parameters/ } \\
\text { references }\end{array}$ & $\begin{array}{c}\text { Gomes } \\
\text { et al. } \\
{[8]}\end{array}$ & $\begin{array}{c}\text { Gomes } \\
\text { et al. } \\
{[8]}\end{array}$ & $\begin{array}{c}\text { Gomes } \\
\text { et al. } \\
{[8]}\end{array}$ & $\begin{array}{c}\text { Gomes } \\
\text { et al. } \\
{[8]}\end{array}$ & $\begin{array}{c}\text { Pardal } \\
\text { et al. } \\
{[51]}\end{array}$ & $\begin{array}{c}\text { Pardal } \\
\text { et al. } \\
{[46]}\end{array}$ & $\begin{array}{c}\text { Pardal } \\
\text { et al. } \\
{[46]}\end{array}$ & $\begin{array}{c}\text { Pardal } \\
\text { et al. } \\
{[52]}\end{array}$ & $\begin{array}{c}\text { Torrez } \\
\text { et al. } \\
\text { [53] }\end{array}$ & $\begin{array}{l}\text { Kallel } \\
\text { et al. } \\
{[12]}\end{array}$ & $\begin{array}{l}\text { Floch } \\
\text { et al. } \\
{[50]}\end{array}$ & $\begin{array}{c}\text { Hommel } \\
\text { et al. } \\
{[11]}\end{array}$ & $\begin{array}{c}\text { Monteiro } \\
\text { et al. } \\
{[45]}\end{array}$ & $\begin{array}{c}\text { Coelho } \\
\text { et. al. } \\
{[44]}\end{array}$ & $\begin{array}{c}\text { Silva } \\
\text { et al. } \\
{[43]}\end{array}$ & $\begin{array}{c}\text { Silva de } \\
\text { Oliveira } \\
\text { et al. } \\
{[30]}\end{array}$ & $\begin{array}{c}\text { Román } \\
\text { et al. } \\
{[14]}\end{array}$ & $\begin{array}{c}\text { Borges } \\
\text { et al. } \\
{[15]}\end{array}$ \\
\hline Scorpion species & $\begin{array}{c}\text { Tityus } \\
\text { metuendus }\end{array}$ & $\begin{array}{l}\text { Tityus } \\
\text { silvestris }\end{array}$ & $\begin{array}{l}\text { Tityus } \\
\text { raquelae }\end{array}$ & $\begin{array}{l}\text { Tityus } \\
\text { apiacas }\end{array}$ & $\begin{array}{l}\text { Tityus } \\
\text { obscurus }\end{array}$ & $\begin{array}{l}\text { Tityus } \\
\text { obscurus }\end{array}$ & $\begin{array}{l}\text { Tityus } \\
\text { obscurus }\end{array}$ & $\begin{array}{l}\text { Tityus } \\
\text { obscurus }\end{array}$ & $\begin{array}{l}\text { Tityus } \\
\text { obscurus }\end{array}$ & $\begin{array}{l}\text { Tityus } \\
\text { obscurus }\end{array}$ & $\begin{array}{l}\text { Tityus } \\
\text { obscurus }\end{array}$ & $\begin{array}{l}\text { Tityus } \\
\text { obscurus }\end{array}$ & $\begin{array}{l}\text { Tityus } \\
\text { silvestris }\end{array}$ & $\begin{array}{l}\text { Tityus } \\
\text { silvestris }\end{array}$ & $\begin{array}{l}\text { Tityus } \\
\text { apiacas }\end{array}$ & $\begin{array}{l}\text { Tityus } \\
\text { strandi }\end{array}$ & $\begin{array}{c}\text { Tityus } \\
\text { cisandinus }\end{array}$ & $\begin{array}{c}\text { Tityus } \\
\text { breweri }\end{array}$ \\
\hline Number of cases & 103 & 22 & 12 & 7 & 72 & 14 & 34 & 1 & 58 & 1 & 1 & 1 & 1 & 13 & 4 & 3 & 20 & 1 \\
\hline Country & Brazil & Brazil & Brazil & Brazil & Brazil & Brazil & Brazil & Brazil & Brazil & $\begin{array}{l}\text { French } \\
\text { Guiana }\end{array}$ & $\begin{array}{l}\text { French } \\
\text { Guiana }\end{array}$ & $\begin{array}{l}\text { French } \\
\text { Guiana }\end{array}$ & Brazil & Brazil & Brazil & Brazil & Ecuador & Venezuela \\
\hline $\begin{array}{l}\text { State/ } \\
\text { Province }\end{array}$ & Amazonas & Amazonas & Amazonas & Amazonas & $\begin{array}{l}\text { Western } \\
\text { Pará }\end{array}$ & $\begin{array}{l}\text { Western } \\
\text { Pará }\end{array}$ & $\begin{array}{l}\text { Eastern } \\
\text { Pará }\end{array}$ & $\begin{array}{l}\text { Eastern } \\
\text { Pará }\end{array}$ & $\begin{array}{l}\text { Western } \\
\text { Pará }\end{array}$ & Cayenne & Cayenne & Cayenne & Amazonas & $\begin{array}{l}\text { Eastern } \\
\text { Pará }\end{array}$ & Amazonas & $\begin{array}{l}\text { Western } \\
\text { Pará }\end{array}$ & $\begin{array}{l}\text { Morona, } \\
\text { Santiago }\end{array}$ & $\begin{array}{c}\text { Eastern } \\
\text { Bolívar } \\
\text { State }\end{array}$ \\
\hline
\end{tabular}

\section{Manifestations}

at the sting site

Dry sting

Paresthesia

Pain

Irradiating pain

Edema

Erythema

Burning sensation

Ecchymosis

Piloerection

Sweating

General

manifestations

Vertigo

Prostration

Sweating

Tremors

Asthenias

General unrest

Goosebumps

Paleness

Priapism

Myalgia

Peripheral cyanosis

Lethargy

$\begin{array}{ccccc}- & - & - & - & - \\ + & + & + & - & + \\ + & + & + & + & + \\ - & - & - & - & + \\ + & + & + & - & + \\ + & + & + & + & - \\ - & - & - & - & + \\ - & - & - & - & + \\ + & - & - & + & + \\ + & - & - & + & -\end{array}$


Table 2. Cont.

\begin{tabular}{|c|c|c|c|c|c|c|c|c|c|c|c|c|c|c|c|c|c|c|}
\hline $\begin{array}{l}\text { Parameters/ } \\
\text { references }\end{array}$ & $\begin{array}{c}\text { Gomes } \\
\text { et al. } \\
{[8]}\end{array}$ & $\begin{array}{c}\text { Gomes } \\
\text { et al. } \\
{[8]}\end{array}$ & $\begin{array}{c}\text { Gomes } \\
\text { et al. } \\
{[8]}\end{array}$ & $\begin{array}{c}\text { Gomes } \\
\text { et al. } \\
{[8]}\end{array}$ & $\begin{array}{c}\text { Pardal } \\
\text { et al. } \\
\text { [51] }\end{array}$ & $\begin{array}{c}\text { Pardal } \\
\text { et al. } \\
{[46]}\end{array}$ & $\begin{array}{c}\text { Pardal } \\
\text { et al. } \\
{[46]}\end{array}$ & $\begin{array}{c}\text { Pardal } \\
\text { et al. } \\
{[52]}\end{array}$ & $\begin{array}{c}\text { Torrez } \\
\text { et al. } \\
\text { [53] }\end{array}$ & $\begin{array}{c}\text { Kallel } \\
\text { et al. } \\
\text { [12] }\end{array}$ & $\begin{array}{c}\text { Floch } \\
\text { et al. } \\
{[50]}\end{array}$ & $\begin{array}{c}\text { Hommel } \\
\text { et al. } \\
{[11]}\end{array}$ & $\begin{array}{c}\text { Monteiro } \\
\text { et al. } \\
{[45]}\end{array}$ & $\begin{array}{c}\text { Coelho } \\
\text { et. al. } \\
{[44]}\end{array}$ & $\begin{array}{c}\text { Silva } \\
\text { et al. } \\
{[43]}\end{array}$ & $\begin{array}{c}\text { Silva de } \\
\text { Oliveira } \\
\text { et al. } \\
{[30]}\end{array}$ & $\begin{array}{c}\text { Román } \\
\text { et al. } \\
{[14]}\end{array}$ & $\begin{array}{c}\text { Borges } \\
\text { et al. } \\
{[15]}\end{array}$ \\
\hline
\end{tabular}

Fever

Rhinorrhea

Gastrointestinal

manifestations

Sialorrhea

Nausea

Vomiting

Diarrhea

Abdominal pain

Hiccup

Odynophagia

Cardiorespiratory

manifestation

Coughing

Dyspnea

Tachycardia

Bradycardia

Hypertension

Hypotension

Tachypnea

Arrhythmia

Respiratory

insufficiency

Ophthalmological

manifestations

Blurry vision

Conjunctival

hyperemia

Photophobia

Miosis

Visual hallucinations

Tearing 
Table 2. Cont.

\begin{tabular}{|c|c|c|c|c|c|c|c|c|c|c|c|c|c|c|c|c|c|c|}
\hline $\begin{array}{l}\text { Parameters/ } \\
\text { references }\end{array}$ & $\begin{array}{c}\text { Gomes } \\
\text { et al. } \\
{[8]}\end{array}$ & $\begin{array}{c}\text { Gomes } \\
\text { et al. } \\
{[8]}\end{array}$ & $\begin{array}{c}\text { Gomes } \\
\text { et al. } \\
{[8]}\end{array}$ & $\begin{array}{c}\text { Gomes } \\
\text { et al. } \\
{[8]}\end{array}$ & $\begin{array}{c}\text { Pardal } \\
\text { et al. } \\
\text { [51] }\end{array}$ & $\begin{array}{c}\text { Pardal } \\
\text { et al. } \\
{[46]}\end{array}$ & $\begin{array}{c}\text { Pardal } \\
\text { et al. } \\
{[46]}\end{array}$ & $\begin{array}{c}\text { Pardal } \\
\text { et al. } \\
{[52]}\end{array}$ & $\begin{array}{c}\text { Torrez } \\
\text { et al. } \\
{[53]}\end{array}$ & $\begin{array}{c}\text { Kallel } \\
\text { et al. } \\
{[12]}\end{array}$ & $\begin{array}{l}\text { Floch } \\
\text { et al. } \\
\text { [50] }\end{array}$ & $\begin{array}{c}\text { Hommel } \\
\text { et al. } \\
{[11]}\end{array}$ & $\begin{array}{c}\text { Monteiro } \\
\text { et al. } \\
\text { [45] }\end{array}$ & $\begin{array}{c}\text { Coelho } \\
\text { et. al. } \\
{[44]}\end{array}$ & $\begin{array}{c}\text { Silva } \\
\text { et al. } \\
{[43]}\end{array}$ & $\begin{array}{c}\text { Silva de } \\
\text { Oliveira } \\
\text { et al. } \\
{[30]}\end{array}$ & $\begin{array}{c}\text { Román } \\
\text { et al. } \\
{[14]}\end{array}$ & $\begin{array}{c}\text { Borges } \\
\text { et al. } \\
{[15]}\end{array}$ \\
\hline
\end{tabular}

Neurological

manifestations

Headache

Drowsiness

Dizziness

Mental confusion

Agitation

Whole body

paresthesia

Myoclonus

"Electric shock"

sensation

Dysmetria

Dysarthria

Ataxic march

Hyperreflexia

Spasticity

Hyperalert

Muscle fasciculations

Motor incoordination

Convulsions

Coma

Romberg signal

Babinski signal

\section{Severity}

Class

Class II

Class III

Class IV (Deaths) 


\section{Physiopathology of Amazonian scorpion envenomation}

The physiopathological mechanism of envenomation by Amazonian Tityus spp., particularly T. obscurus that explains its clinical outcome has not yet been fully elucidated. However, growing toxicological and physiological evidence suggests out that it differs significantly from the autonomic exacerbation mechanism reported for other buthid scorpions.

Three physiological paths of phenomena have been invoked to explain neurological complications after envenomation by scorpion species mainly producing autonomic manifestations. First, cerebral damage can be elicited by excessive blood pressure because of the scorpion toxin-induced peripheral massive release of catecholamines [66]. Also, brain ischemia could result from a defect in oxygen transport secondary to the pulmonary edema and cardiogenic shock observed in severely envenomed patients [67]. A third hypothesis is the direct action of scorpion toxins on the central nervous system (CNS). In this sense, ClotFaybesse et al. [68] have suggested that neurological sequelae in envenomed infants are a consequence of their blood-brain barrier being significantly more permeable to scorpion toxins than adults. The fact that no significant passage of scorpion toxin of the blood-brain barrier occurs in adult mice and rats has been taken to indicate that CNS toxicity in adults is likely the result of the venom's peripheral action, at least in the case of toxic Old World species (e.g. genera Androctonus and Leiurus) $[69,68]$. As for Amazonian Tityus spp. producing neurological alterations in both infants and adults, where the appearance of adrenergic/cholinergic stimulation is less frequent or even absent, an alternative mechanism needs to be proposed. Torrez et al. [53] suggested that the neurological symptomatology presented after T. obscurus envenomation is the result of an acute cerebellar dysfunction together with abnormal neuromuscular manifestations. Silva de Oliveira et al. [30] proposed the possibility that these venoms, particularly $T$. obscurus, contain toxins with a higher affinity for ion channels expressed on sensory neuronal membranes (pain and sensation of "electric shock" in T. obscurus and T. strandi), motor neurons (hypertonia, fasciculation, myoclonus and spasm) and in CNS neurons (ataxia), with less affinity for ion channels expressed by peripheral neurons. In support of the latter possibility, it is known that scorpion toxins active on sodium channels (the most lethal components of buthid scorpion venoms) exhibit exquisite specificity towards channel's subtypes [70], and that there is a differential expression pattern of such subtypes across nervous system tissues [71]. For instance, toxin LqhII from Leiurus haebreus is more potent towards sodium channel subtypes expressed in peripheral nervous system compared with LqhIII, from the same venom, which is significantly more active towards subtypes expressed in the brain [72].

Regarding the proposed action at the cerebellar level of $T$. obscurus and possibly other Amazonian Tityus toxins, no direct evidence is available at present. Significantly, recent work has suggested the importance of cerebellar neuronal dysfunction resulting from mutations in specific ion-channels that regulate membrane excitability in the pathogenesis of cerebellar ataxia in humans [73]. While various channelopathies in both sodium and potassium channels have been associated to cerebellar ataxia, some forms of gait ataxia have been recently linked to loss-offunction mutation on the BK (large conductance, calciumactivated potassium) channel which affects its selectivity filter reducing channel conductance and ion selectivity [74]. In this sense, CNS-specific potassium and/or sodium channel toxins may be produced by Amazonian Tityus, particularly in the $T$. obscurus group (e.g T. obscurus and T. cisandinus), that could account for the cerebellar alterations, including gait ataxia, which could act synergistically with other toxin types on specific channel subtypes expressed in motor and sensory neurons. If such T. obscurus CNS-specific toxins exist, a mechanism has to be postulated to explain their crossing of the blood-brain barrier in adult individuals.

Pulmonary edema, generally the cause of death induced by buthid scorpion venoms (including T. serrulatus), can have a cardiogenic origin as a result of the venom-induced massive release of catecholamines and depressed left ventricular systolic function, and also a noncardiogenic component, related to increased vascular permeability due to the activation of inflammatory mediators [75]. In fact, a cytokine storm initiates inflammatory-induced multi-organ dysfunction, often leading to an acute respiratory distress syndrome [76]. In rats, T. obscurus venom (10 mg/kg, i.p.) causes hemorrhagic patches in lung parenchyma but does not lead to lung edema [47]. The absence of edema in the case of $T$. obscurus implies the existence of a different mechanism of venomelicited lung damage. Significantly, in the case of South African $P$. transvaalicus envenomation, where similar neuromuscular disturbances to T. obscurus have been reported, predominant cholinergic (instead of adrenergic) stimulation is protective of pulmonary edema [64]. It remains to be established in the case of T. obscurus, which neurotransmitters are associated with scorpion venom activity, generally resulting in presynaptic depolarization [77], and also which inflammatory mediators are produced as a result of the envenomation for a better understanding of the aetiology of lung disturbances in these cases.

Pulmonary disturbances vary across Amazonia, as cases by $T$. metuendus and the T. obscurus population inhabiting the area of Cayenne (French Guiana) present with dyspnea and respiratory insufficiency $[8,11]$, whereas envenomation by T. obscurus and T. silvestris from Pará, Brazil, do not [46, 44]. This suggests that different mediators associated to lung damage may be involved because of species- and/or populationspecific toxinological differences across the Basin. Particularly, manifestations after T. metuendus envenomation, the species of greatest epidemiological importance in the Manaus region, resemble that of T. serrulatus and T. bahiensis in the Brazilian southeast [8], although $6 \%$ of the cases presents with myoclonia, a feature lacking by the latter species' envenomation. Pediatric cases of scorpion envenomation in areas of French Guiana 
(where Tityus spp. are prevalent, including T. obscurus) present with a combination of cholinergic (including bradycardia, hypersecretion, and bronchoconstriction) and adrenergic (e.g. tachycardia, seizures) manifestations, in addition to neurological alterations [9]. Leukocytosis and hyperglycemia, known markers of poor prognosis in scorpionism [78, 79], are also present in these cases. These clinical alterations differ from the mainly central manifestations observed in cases from western Pará, Brazil, by T. obscurus [46]. The toxinological basis for such differences in clinical manifestations are not yet evident but comparative transcriptomic and phylogenetic studies, particularly across $T$. obscurus distribution, should throw light on whether populationspecific toxin repertoires are produced despite the strong phylogenetic association predicted for Amazonian species (Figure 4). In this sense, our phylogeny demonstrates a $12.02 \%$ $\mathrm{CO} 1$ divergence (uncorrected p-distance) between eastern and western Brazilian T. obscurus populations, which may underlie differences in ion channel-specific toxin expression patterns as recorded in the case of populations of the Chinese scorpion Lychas mucronatus [80]. Molecular clock estimates suggest that the two populations shared a common ancestor in the Miocene, an evolutionary depth usually attributed to different species in scorpions [81, 82]. Thus, T. obscurus likely represents at least two morphologically similar but toxinologically disparate species.

Regarding effects at the muscular level, Borja-Oliveira et al. [83] showed that T. obscurus venom exerts a positive inotropic effect on mouse diaphragm; i.e. it is able to potentiate contractile force in directly stimulated curarized muscles (when neuromuscular transmission is abolished by the acetylcholine competitive antagonist D-tubocurarine), indicating that this venom contains factors that can efficiently increase contractile force by acting directly on the sarcolemma. On the contrary, D-tubocurarine prevented the inotropic effect of T. serrulatus venom in the same preparation, indicating that its muscular effect is acetylcholine-dependent. This is additional evidence that venom composition and activity in T. obscurus, and possibly in other related Amazonian species, differ significantly from other congeneric species responsible for severe scorpionism in South America, mainly T. serrulatus.

Altogether, more research needs to be directed towards elucidation of Amazonian Tityus envenomation physiopathology, especially considering that species and population-specific clinical trends are evident across the Amazon River basin. Fortunately, efforts have already been made to understand the biochemical and physiological mechanisms of action in isolated T. obscurus sodium channel toxins (see following section).

\section{Molecular, biochemical, and electrophysiological studies on Amazonian scorpion venoms}

Research to uncover the composition and physiological activity of Amazonian Tityus venoms has focused on T. obscurus and lately on T. metuendus. The two species accounted for the majority of envenomation cases in urban areas, and the studies mostly evaluated ion channel specificity or biomedical applications of native or synthetically derived venom components.

\section{Venom toxic components from Tityus obscurus}

Batista et al. [84-87] were the first to characterize the toxins produced by T. cambridgei (later synonymed with T. obscurus) from specimens collected at Marajó Island, Pará state, Brazil, using a combination of high performance liquid chromatography and mass spectrometry, with more than 60 isolated components. Of these, 26 peptides were characterized by mass spectrometry and physiologically as toxins targeting sodium or potassium channels. Guerrero-Vargas et al. [48] later proceeded with the molecular cloning of T. obscurus toxins (primary structure of fifteen putative sodium channel toxins was characterized) and performed phylogenetic analyses to uncover the relationships of T. obscurus sodium channel-active toxins and those from available congeneric species. They postulated that a strong cladistic separation exist between toxins from the northern part of the Amazon basin and those produced by congeneric scorpions inhabiting southeast South America. This result is corroborated by our phylogenetic results (Figure 4).

Oliveira et al. [88] performed the first transcriptomic analysis of T. obscurus venom, combined with a proteomic analysis. Results confirmed primary structures of previously identified components and concluded that a high abundance of metalloproteinases is followed by sodium and potassium channel toxins, which together with proteases are the most abundant components in the venom. In addition to ion channel-active toxins, scorpion metalloproteinases are important venom components as they have been shown to hydrolyze neuropeptides in vitro, releasing mediators that could interact with ion channels and promote indirect neurotoxicity [89]. The work by Oliveira et al. was able to identify several T. obscurus putative venom components such as the following: anionic peptides, antimicrobial peptides, bradykininpotentiating peptide, cysteine rich protein, serine proteinases, cathepsins, angiotensin-converting enzyme, endothelinconverting enzyme and chymotrypsin like protein, proteinases inhibitors, phospholipases and hyaluronidases. Importantly, their work reported that while major secreted venom component classes are highly similar among T. obscurus and T. serrulatus, their individual toxin sequences are considerably divergent, confirming previous findings by Guerrero-Vargas et al. [48].

Recently, Dias et al. [90] determined that approximately 5\% of crude T. obscurus venom is composed of short linear, nondisulfide-bridged peptides (NDBP). As opposed to disulfidebridged peptides, responsible for the venom neurotoxic effects, NDPBs display a cationic amphipathic a-helical structure which allows ample antibacterial, antifungal, antiviral, and cytolytic activities [91]. They characterized 27 major peptides among T. obscurus NDBPs, which were sequenced, and thirteen were synthetized and functionally characterized. Some of the novel peptides showed similarity to hypotensins, potassium channel toxins and the allergen 5 protein, but most do not match 
any known toxin. Some of these peptides showed a moderate increase in nociceptive sensibility and edematogenic activity after intraplantar administration in mice, and have been suggested to act synergistically to alter rearing or locomotion in prey/predators of T. obscurus by potentiating inflammatory processes [90]. Chemically synthesized NDPBs ToAP3 and ToAP4 (derived from cDNAs coding for putative T. obscurus antimicrobial peptides) inhibit inflammatory responses, decreasing the production of various inflammatory mediators and modulating dendritic cells' activation and maturation, avoiding exacerbated inflammatory reactions. Besides, ToAP3 showed antibacterial activity against Mycobacterium massiliense [92]. A novel enzyme inhibitor (ToPI1) has been isolated from T. obscurus venom, which specifically targets trypsin and undergoes head-to-tail cyclization upon enzyme binding. It has been proposed that this peptide and its derivatives could be used as activity based-probes to image trypsin activity in live animals and tissues. Although ToPI1 is related structurally to potassium channel toxins, its reduced activity against several of these channels suggest fewer adverse effects from their possible therapeutic application [93].

Table 3 presents native venom components from T. obscurus which primary structure and function has been determined to date. Work by Tibery et al. [94] and Duque et al. [95] have unveiled the sodium channel subtype specificity of neurotoxins Tol and To4. Toxin To1, previously shown to change sodium permeation in rat cerebellum granular neurons, has been classified as a $\beta$-toxin. This is because it mainly affects the gating activation component of human sodium channel isoforms hNav1.3 and hNav1.6, which are the subtypes mostly expressed on cerebellar granular cells [96]. To4 is also a $\beta$-toxin mainly affecting hNavl.1,
hNav1.2, and hNav1.4 isoforms. This work, taken together with the electrophysiological characterization of other Tityus $\beta$-toxins, underscores the exquisite sodium channel subtype specificity among toxins from species across the geographical distribution of this genus. Different sodium channel-active toxins have different abilities to promote neurotransmitter release [97]. Such differential specificity may have physiopathological implications as there is a correlation between clinical manifestations and the type of neurotransmitter being released as a result of the envenomation process [6]. This remains to be explored in the case of T. obscurus and related species, particularly considering that autonomic manifestations are few or even absent, at least in the case of T. obscurus populations inhabiting Amazonia in eastern Brazil.

Regarding T. obscurus toxins targeting potassium channels, three components have been isolated an evaluated. Toxin Tc1, a 23 amino acid-long, highly charged (30\% positively charged residues) peptide, targets not only the Shaker B K+ channel but other voltage-gated potassium channels present in the brain [86]. Toxins Tc30 and Tc32 have a high affinity for Kv1.3 channels expressed on human T lymphocytes, although they are poor blockers of Shaker B K+ channel [87]. More T. obscurus toxins acting on $\mathrm{K}+$ channels remain to be characterized, as the transcriptomic and proteomic analyses of Oliveira et al. [88] recovered the sequences of 33 components putatively targeting potassium channels. A plausible role for potassium channelspecific Amazonian toxins in cerebellar pathology also needs to be explored. These toxins generally target the channel's selectivity filter [100], a structural region where disease-related mutations have been linked to motor disorders.

Table 3. Physiologically and structurally characterized native components from $T$. obscurus venom.

\begin{tabular}{|c|c|c|c|}
\hline $\begin{array}{l}\text { Component } \\
\text { (UniProtKB/PDB) }\end{array}$ & $\begin{array}{l}\text { Venom class/ } \\
\text { Peptide mass }\end{array}$ & Ascribed function & Reference \\
\hline To1 (P60214) & $\mathrm{NaTx}(7403.5 \mathrm{Da})$ & 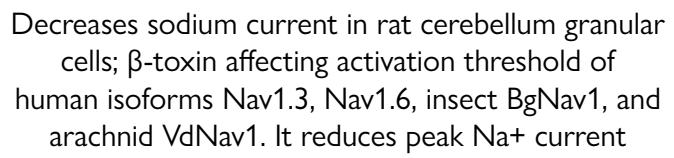 & {$[84]$} \\
\hline To2 (P60212) & $\mathrm{NaTx}(7318.4 \mathrm{Da})$ & a-toxin activity in F-11 cell lines & [85] \\
\hline To4 (P60215) & $\mathrm{NaTx}(7253.5 \mathrm{Da})$ & $\begin{array}{l}\beta \text {-toxin affecting activation threshold of human } \\
\text { isoforms Nav1.1, Nav1.2, and Nav1.6 }\end{array}$ & [94] \\
\hline Tc1 (P83243) & KTx (2446.4 Da) & $\begin{array}{l}\text { It blocks reversibly Shaker BK(+)-channels; solution } \\
\text { structure available }\end{array}$ & {$[86,99]$} \\
\hline ToPI1 (6MRQ_I) & Trypsin inhibitor (3806.9 Da) & $\begin{array}{l}\text { Specifically targets trypsin over chymotrypsin; } \\
\text { undergoes cyclization upon enzyme binding }\end{array}$ & [93] \\
\hline
\end{tabular}




\section{Venom toxic components from Tityus metuendus}

T. metuendus venom (from specimens collected in the Manaus region) has been recently studied using mass fingerprinting analysis, with the identification of over 200 distinct molecular mass components. At least 60 sub-fractions were recovered using high performance liquid chromatography and five purified peptides were sequenced by Edman degradation. An electrophysiological assay of whole T. metuendus soluble venom demonstrated the presence of both $\alpha$ - and $\beta$-scorpion toxin types. The gating processes of sodium channel subtypes hNav1.1, hNav1.2, hNav1.6, and hNav1.7 exhibited both alpha (current inactivation) and beta (current activation) effects, whereas venom modification of isoform hNavl.4 only showed a beta effect [101]. Importantly, T. metuendus venom contained a significant number of homologs to T. obscurus toxins belonging to bradykinin-potentiating peptide, potassium and sodium channel toxin venom families. This adds further support to the notion that scorpion toxins with a similar structural/functional fingerprint probably exist throughout Amazonia, supported by the phylogenetic relationships of species sequenced thus far, including T. metuendus (Figure 4).

\section{Antivenom neutralization efficiency and antigenicity of Amazonian scorpion toxic components}

A major concern in the treatment of scorpion envenomation in the Amazon region has been the reduced neutralization capacity of some clinical manifestations by available antivenoms, combined with the limited access to these immunobiologicals in remote, rural areas of the basin. Prompt application of equinederived scorpion antivenom (in combination with appropriate supportive measures) is a proven therapeutic tool worldwide as specific immunoglobulins effectively clear circulating scorpion venom antigens, particularly in patients where severe manifestations are yet to develop $[1,102]$. In the case of Brazilian Amazonia, available antivenoms are those produced against T. serrulatus and an anti-arachnidic polyvalent serum against Phoneutria and Loxosceles spiders and Tityus venoms [8, 51, 53]. No antivenom is currently used in French Guiana against scorpion envenomation [9]. In Amazonian Venezuela, the antiTityus discrepans antivenom has been used to treat envenomation by T. breweri [15]. In the Shuar communities of Morona Santiago, Amazonian Ecuador, where envenomation by T. cisandinus is frequent, the clinical approach has relied on supportive treatment as no scorpion antivenom is available in Ecuador [14]. The same goes for remote jungle areas of Guyana [13]. Torrez et al. [53] have pointed out that the anti-T. serrulatus antivenom did not significantly reduce the severity of the cerebellar-muscular manifestations elicited by T. obscurus envenomation in the area of Santarem, Pará state, Brazil, with the need to resorting to benzodiazepines for treatment. Gomes et al. [8] also explained that neurological manifestations in patients stung by T. apiacas did not improve upon administration of the anti-T. serrulatus antivenom. In some cases of envenomation by T. strandi, the intensity and body distribution of the "electric shock" sensation did not subside with serotherapy using this antivenom [30]. However, muscle spasms manifested in $6 \%$ of T. metuendus envenomation cases from the Manaus region, and usually ended about 6-8 h after serotherapy [8].

The fact that the some of the neurological manifestations in T. obscurus, T. apiacas, and possibly T. strandi, are refractory to treatment with the Brazilian scorpion antivenom is indicative of the existence of different toxin antigenic epitopes in these Amazonian species. This is due to significant amino acid sequence divergence between ion channel specific toxins from Amazonian and southeast Tityus spp. [88, 48]. Interestingly, the actual recognition of the low molecular mass fraction of $T$. obscurus venom is negligible in immunoblots upon reaction with anti-T. serrulatus antibodies [88]. Such lower reactivity towards T. obscurus venom antigens, in comparison with T. serrulatus, $T$. bahiensis, and T. stigmurus, has also been demonstrated when using sera from the three different manufacturers of scorpion antivenoms in Brazil in ELISA assays [103].

\section{The need for specific scorpion antivenoms for the Amazon region}

Only three anti-Tityus antivenoms are produced in Latin America [anti-T. serrulatus (three producing institutions in Brazil), anti-T. discrepans (Venezuela), and anti-T. trivittatus (Argentina)] for treating envenomations by at least 30 species of proven medical importance in this genus [6]. Borges et al. [33] proposed partitioning the Tityus fauna into four venom antigenic areas that could guide the use of currently available antivenoms or suggest the preparation of new antibodies, particularly in the case of Amazonia. Immunochemical, molecular (cDNA cloning), and phylogenetic data point out the existence of a distinct toxinological area encompassing morphologically related Tityus spp. (e.g all have two ventromedian keels in metasomal segments II to IV) inhabiting Lower Central America (LCA), Colombia, and the Amazon region. The stronger immunochemical recognition of the low molecular mass fraction of venoms from these origins by the Venezuelan (anti-T. discrepans), compared to the Brazilian anti-T. serrulatus, indicates conservation of linear epitopes among T. discrepans and LCA-Colombian-Amazonian species. Competitive ELISA assays involving soluble proteins from the same venoms also indicate that congeneric species from this region share native conformational epitopes with $T$. discrepans to a greater extent than with southeast Brazilian species, suggesting similar toxin surface chemistries. Both linear and conformational epitopes are known to be involved in antibody recognition of scorpion sodium channel toxins [104]. This affinity is further supported by the phylogenetic association of Tityus toxins in this group, where $\beta$-toxins from Venezuela, LCA and Amazonia cluster separately from $\beta$-toxins from southeast South America. 
Homologs of T. obscurus To2, To3, To4, To8, and To11 are found throughout the LCA-Colombian-Amazonian region [33]. However, in vivo experiments have indicated that the amount of Venezuelan antivenom required for effective neutralization in the region might be greater than that required to neutralize venom from T. discrepans and allied Venezuelan species. Venom neutralization of $T$. perijanensis, a species that belongs to the Amazon region based on toxinological criteria, requires three times as much anti-T. discrepans antivenom to neutralize the control venom. Immunochemical data indicate that the anti-T. discrepans antivenom is the best available treatment for scorpionism in Amazonia. That said, the aim in serotherapy is the use of highly specific antibodies for neutralization of circulating venom antigens, so we anticipate the need to prepare new neutralizing antibodies against Tityus spp. inhabiting this region. Additionally, it remains to be determined whether the Venezuelan antibodies are capable of neutralizing neurological manifestations characteristic of scorpionism in the region. These new antidotes should be of particular help in French Guiana, Colombia, Ecuador, Peru, and throughout the Amazon region of Brazil.

\section{Conclusions}

Much remains to be done in Amazonia in regard to the design of effective therapeutic tools to treat scorpionism. A multicentric approach involving research and medical facilities in all affected areas should prove rewarding. In this sense, a joint effort between scorpion biologists and toxinological/medical teams to keep ascribing clinical cases and venom components to confirmed species is clearly needed. Health workers seeking specific information on the control, prevention, and treatment of Tityus envenomations, mainly by Brazilian species, are suggested to review recent publications on the subject [5]. Concerning the possibility of producing a Pan-Amazonian scorpion antivenom, the observation that recognition of Tityus low molecular mass components from Venezuelan and Central American is greatly increased when a mixture of several Tityus venoms is used as antigen could guide future immunization protocols for the preparation of polyvalent therapeutic antibodies effective in the region [33]. In parallel, transcriptomic/proteomic studies of other medically important species could help demonstrate the degree of shared components along the basin. As a consequence of such studies, preparation of chimeric proteins containing epitopes from main toxic and immunogenic Tityus venom components of the LCA/Colombian/Amazonian corridor, as similarly designed for crotoxin [105], would be instrumental as representative antigens for the preparation of neutralizing antibodies with a broad range of efficacy.

Tityus is the most species rich scorpion genus, so it is perhaps unsurprising that their venoms are also exceptionally diverse. Fortunately, some patterns are beginning to emerge, and as demonstrated by this review, venom diversity is better understood when also considering phylogenetic relationships. Our molecular phylogenetic analysis of medically significant Tityus from
Amazonia supports this stance, as Amazonian species with venoms that present unique neurological complications form a monophyletic group. Thus, some aspects of Tityus venoms exhibit phylogenetic signal, an outcome that can aid the development of antivenom treatments. Additional sampling of poorly sampled regions in Amazonia would further benefit our growing understanding of Tityus spp. and their venoms, especially if studied in a cross-disciplinary context that includes phylogenetics. Such an approach would undoubtedly reveal new scorpion species. Some of these will likely be related to the medically significant Amazonian Tityus reviewed in this study, a group that has probably inhabited the region's rainforests since the Miocene.

\section{Acknowledgments}

The authors wish to thank the reviewers for their useful comments.

\section{Availability of data and materials}

Not applicable.

\section{Funding}

Research presented in this article was funded by the National Council for Scientific Research (Conacyt), Paraguay, Project PRID18-12 (to AB).

\section{Competing interests}

The authors declare that they have no competing interests.

\section{Authors' contributions}

$\mathrm{AB}$ conceived the idea for the manuscript and wrote the original draft. MRG performed phylogenetic analyses and contributed with drafting the original manuscript. PPOP performed analyses of clinical data and contributed with drafting the original manuscript. DMC contributed with the analyses of scorpion distribution in the Amazon region and participated in the drafting of the original manuscript. All authors read the manuscript and approved it.

\section{Ethics approval}

Not applicable.

\section{Consent for publication}

Not applicable.

\section{Supplementary material}

The following online material is available for this article:

Additional file 1. Uncorrected p-distances (lower diagonal) and $\mathrm{K} 2 \mathrm{P}$ corrected distances (upper diagonal) among COI sequences from medically important Tityus species. 


\section{References}

1. Amaral CFS, Rezende NA. Treatment of scorpion envenoming should include both a potent specific antivenom and support of vital functions. Toxicon. 2000 Aug;38(8):1005-7.

2. Chippaux JP, Celis A, Boyer L, Alagón A. Factors involved in the resilience of incidence and decrease of mortality from scorpion stings in Mexico. Toxicon. 2020 Dec;188:65-75. doi: 10.1016/j.toxicon.2020.10.011.

3. Chippaux JP, Alagón AC. Envenimations et empoisonnements par les animaux venimeux ou vénéneux VII: L'arachnidisme du Nouveau Monde. Med Trop (Mars). 2008 Jun;68(3):215-21.

4. Hui Wen F, Monteiro WM, Moura da Silva AM, Tambourgi DV, Mendonça da Silva I, Sampaio VS, dos Santos MC, Sachett J, Ferreira LCL, Kalil J, Lacerda M. Snakebites and scorpion stings in the Brazilian Amazon: identifying research priorities for a largely neglected problem. PLoS Negl Trop Dis. 2015 May 21;9(5):e0003701. doi: 10.1371/journal.pntd.0003701.

5. Monteiro WM, Gomes J, Fé N, Mendonça da Silva I, Lacerda M, Alencar A, Seabra de Farias A, Val F, de Souza Sampaio V, Cardoso de Melo G, Pardal P, Mota da Silva A, Bernarde PS, de Lima Ferreira LC, Gutierrez JM, de Almeida Gonçalves Sachett J, Fan HW. Perspectives and recommendations towards evidence-based health care for scorpion sting envenoming in the Brazilian Amazon: a comprehensive review. Toxicon. 2019 Nov;169:68-80. doi: 10.1016/j.toxicon.2019.09.003.

6. Borges A, Graham MJ. Phylogenetics of scorpions of medical importance. In: Gompalanokrishnanone P, Calvete JJ, editors. Venom Genomics and Proteomics. Dordrecht: Springer Netherlands; 2016. p. 81-103.

7. Queiroz AM, Sampaio VS, Mendonça I, Fé NF, Sachett J, Ferreira LCL, Feitosa E, Wen FH, Lacerda M, Monteiro W. Severity of scorpion stings in the Western Brazilian Amazon: a case-control study. PLoS One. 2015 Jun 10;10(6): e0128819.

8. Gomes JV, Fé NF, Santos HLR, Jung B, Bisneto PF, Sachett A, de Moura VM, Mendonça da Silva I, Cardoso de Melo G, Pereira de Oliveira Pardal P, Lacerda M, Sampaio V, Wen FH, de Almeida Gonçalves Sachett J, Monteiro WM. Clinical profile of confirmed scorpion stings in a referral center in Manaus, western Brazilian Amazon. Toxicon. 2020 Nov;187:245-54. doi: 10.1016/j.toxicon.2020.09.012.

9. Vaucel J, Mutricy R, Hoarau M, Pujo JM, Elenga N, Labadie M, Kallel h. Pediatric scorpionism in northern Amazonia: a 16-year study on epidemiological, environmental and clinical aspects. J Venom AnimToxins incl Trop Dis. 2020 Sep 11;26:e202000038.

10. Benmosbah M, Guegueniat P, Mayence C, Egmann G, Narcisse E, Gonon $\mathrm{S}$, Hommel D, Kallel H. Epidemiological and clinical study on scorpionism in French Guiana. Toxicon. 2013 Oct; 73:56-62.

11. Hommel D, Hulin A, Lourenço WR. Accident scorpionique létal par Tityus cambridgei Pocock: à propos d'un cas en Guyane Française. Concours médical (Paris). 2000;122(7):481-4.

12. Kallel $H$, Mayence $C$, Guegueniat $P$, Hommel D. Acute necrotizing pancreatitis after Tityus obscurus scorpion envenomation in French Guiana. J Clin Toxicol. 2016;6(6):1000328.

13. Iserson KV, Jagit Ramcharran SD. Black scorpion (Tityus obscurus) fatalities in Guyana and a literature review. J Emerg Med. 2019 Oct;57(4):554-9. doi: 10.1016/j.jemermed.2019.07.018.

14. Román JP, García F, Medina D, Vásquez M, García J, Graham MR, RomeroAlvarez D, Pardal PPO, Ishikawa EAY, Borges A. Scorpion envenoming in Morona Santiago, Amazonian Ecuador: molecular phylogenetics confirms involvement of the Tityus obscurus group. Acta Trop. 2018 Feb;178:1-9. doi: 10.1016/j.actatropica.2017.10.014.

15. Borges A, Rojas-Runjaic FJM, Diez N, Faks JG, Op den Camp HJM, De Sousa L. Envenomation by the scorpion Tityus breweri in the Guayana Shield, Venezuela: report of a case, efficacy and reactivity of antivenom, and proposal for a toxinological partitioning of the venezuelan scorpion fauna. Wilderness Environ Med. 2010 Dec;21(4):282-90.

16. Bravo Suárez MP, Zamora Suárez A, Mondragón Cardona A. Disfunción autonómica debido a accidente escorpiónico: reporte de caso. Acta Méd Peruana. 2017;34(1):49-51.

17. da Silva JMC, Rylands $A B$, da Fonseca GAB. The fate of the Amazonian areas of endemism. Conservation Biol 2005 Jun 7;19(3):689-94.
18. Solomon SE, Bacci Jr M., Martins Jr J, Vinha GG, Mueller UG. Paleodistributions and comparative molecular phylogeography of leafcutter ants (Atta spp.) provide new ensight into the origins of Amazonian diversity. PLOS One. 2008 Jul 23;3(7):e2738. doi: 10.1371/journal.pone.0002738.

19. Hall JPW, Harvey DJ. The phylogeography of Amazonia re-visited: new evidence from riodinid butterflies. Evolution 2002 Jul;56(7):1489-97.

20. Lourenço WR, Rossi A, Wilmé L. Further clarifications on species of Tityus C. L. Koch, 1836, subgenus Atreus Gervais, 1843 (Scorpiones: Buthidae), from Amazonia, with the description of a new species. Riv Arac Italiana. 2019 May;21:11-25.

21. Adis J, Harvey MS. How many Arachnida and Myriapoda are there world-wide and in Amazonia? Studies Neotropical Fauna Envir. 2000 Jan 1;35(2):139-41. doi: 10.1076/0165-0521(200008)35:2;1-9;ft139.

22. Lourenço WR. Scorpiones. In: Adis J, editor. Amazonian Arachnida and Myriapoda. Sofia-Bulgaria: Pensoft Publishers; 2002. p. 399-438.

23. Lourenço WR. The distribution of noxious species of scorpions in Brazilian Amazonia: the genus Tityus C. L. Koch, 1836, subgenus Atreus Gervais, 1843 (Scorpiones, Buthidae). Entomol Mitt Zool Mus Hamburg. 2011 Jul 1;15(185):287-301.

24. Nishikawa AK, Caricati CP, Lima MLSR, Dos Santos MC, Kipnis TL, Eickstedt VRD, Knysak I, Da Silva MH, Higashi HG, Da Silva WD. Antigenic cross-reactivity among the venoms from several species of brazilian scorpions. Toxicon. 1994 Aug;32(8):989-98. doi: 10.1016/00410101(94)90377-8.

25. Dupré G. Checklist of scorpions' taxa 1758-2020. Arachnides. 2021;100:2-111.

26. Ythier E. A synopsis of the scorpion fauna of French Guiana, with description of four new species. ZooKeys. 2018 Jun 5;764:27-90.

27. Ochoa JA, Rojas-Runjaic FJM. Scorpions. In: Rull V, Vegas-Vilarrúbia T, Huber O, Señaris C, editors. Biodiversity of Pantepui: The Pristine "Lost World" of the Neotropical Guiana Highlands. New York: Academic Press; 2019. p. 223-46.

28. González-Sponga MA. Guía para Identificar Escorpiones de Venezuela. Caracas: Cuadernos Lagoven; 1996.

29. Lourenço WR. Synopsis of the colombian species of Tityus Koch (Chelicerata, Scorpiones, Buthidae), with descriptions of three new species. J Nat Hist. 2000;34(3):449-61.

30. Silva de Oliveira SM, Bertani R, Quispe Torrez PP, Lopes de Sousa PR, Martinez Quiroga MM, Bertolozzi MR, de Siqueira Franca FO. Electric shock sensation in the first reports of envenomations by Tityus strandi in the Brazilian Amazon. Toxicon. 2020 Apr 30;178:8-12. doi: 10.1016/j. toxicon.2020.01.005.

31. Borges A, Bermingham E, Herrera N, Alfonzo MJ, Sanjur Ol. Molecular systematics of the neotropical scorpion genus Tityus (Buthidae): the historical biogeography and venom antigenic diversity of toxic venezuelan species. Toxicon. 2010 Feb-Mar;55(2-3):436-54. doi: 10.1016/j.toxicon.2009.09.011.

32. Ojanguren-Affilastro AA, Adilardi RS, Mattoni Cl, Ramírez MJ, Ceccarelli FS. Dated phylogenetic studies of the southernmost American buthids (Scorpiones; Buthidae). Mol Phylogenet Evol. 2017 May;110:39-49.

33. Borges A, Lomonte B, Angulo Y, de Patiño HA, Pascale JM, Otero R, Miranda RJ, De Sousa L, Graham MR, Gómez A, Pardal PPO, Ishikawa E, Bonilla F, Castillo A, de Avila RAM, Gómez JP, Caro-López JA. Venom diversity in the neotropical scorpion genus Tityus: implications for antivenom design emerging from molecular and immunochemical analyses across endemic areas of scorpionism. Acta Tropica. 2020 Apr;204:105346. doi: 10.1016/j.actatropica.2020.105346.

34. Esposito LA, Yamaguti HY, Pinto-da-Rocha R, Prendini L. Plucking with the plectrum: phylogeny of the New World buthid scorpion subfamily Centruroidinae Kraus, 1955 (Scorpiones: Buthidae) reveals evolution of three pecten-sternite stridulation organs. Arthropod Syst Phylogeny. 2018;76(1):87-122.

35. Edgar RC. MUSCLE: multiple sequence alignment with high accuracy and high throughput. Nucleic Acids Res. 2004 Mar 19;32(5):1792-7. doi:10.1093/nar/gkh340.

36. Kumar S, Stecher G, Li M, Knyaz C, Tamura K. MEGA X: Molecular Evolutionary Genetics Analysis across computing platforms. Mol Biol Evol. 2018 Jun 1;35(6):1547-9. 
37. Drummond AJ, Suchard MA, Xie D, Rambaut A. Bayesian phylogenetics with BEAUti and the BEAST 1.7. Mol Biol Evol. 2012 Aug;29(8):1969-73. doi:10.1093/molbev/mss075.

38. Borges A, Rojas-Runjaic FJM. Tityus perijanensis González-Sponga (Scorpiones, Buthidae): molecular assessment of its geographical distribution and venom lethality of venezuelan populations. Toxicon. 2007 Dec 1;50(7):1005-10.

39. Maria WS, Velarde DT, Alvarenga LM, Nguyen C, Villard S, Granier C, Chávez-Olórtegui C. Localization of epitopes in the toxins of Tityus serrulatus scorpions and neutralizing potential of therapeutic antivenoms. Toxicon. 2005 Aug;46(2):210-7. doi:10.1016/j.toxicon.2005.03.024.

40. Lourenço WR. Nouvelle proposition de découpage sous-générique du genre Tityus C.L. Koch, 1836 (Scorpiones, Buthidae). Bol SEA. 2006;39:55-67.

41. Borges A, Jowers MJ, Bónoli S, De Sousa L. Scorpions from the primeval subgenus Archaeotityus produce putative homologs of Tityus serrulatus toxins active on voltage-gated sodium channels. J Venom Anim Toxins incl Trop Dis. 2012;18(4):432-40.

42. Borges A, Morales M, Loor W, Delgado M. Scorpionism in Ecuador: first report of severe and fatal envenomings in northern Manabí by Tityus asthenes Pocock. Toxicon. 2015 Oct;105:56-61.

43. da Silva BAJ, Fé NF, Gomes AAS, Souza AS, Sachett JAG, Fan HW, de Melo GC, Monteiro WM. Implication of Tityus apiacas (Lourenco, 2002) in scorpion envenomations in the southern Amazon border, Brazil. Rev Soc Bras Med Trop. 2017 May-Jun;50(3):427-30.

44. Coelho JS, Ishikawa EAY, dos Santos PRSG, Pardal PPO. Scorpionism by Tityus silvestris in eastern Brazilian Amazon. J Venom Anim Toxins incl Trop Dis 2016 Aug 26;22(1):24.

45. Monteiro WM, de Oliveira SS, Pivoto G, Alves EC, Sachett JAG, Alexandre CN, Fé NF, Barbosa Guerra MG, da Silva IM, Tavares AM, Ferreira LCL, Lacerda MVG. Scorpion envenoming caused by Tityus cf. silvestris evolving with severe muscle spasms in the Brazilian Amazon. Toxicon. 2016 Sep 1;119:266-9.

46. Pardal PP, Ishikawa EA, Vieira JL, Coelho JS, Dórea RC, Abati PA, Quiroga MM, Chalkidis HM. Clinical aspects of envenomation caused by Tityus obscurus (Gervais, 1843) in two distinct regions of Pará state, Brazilian Amazon basin: a prospective case series. J Venom Anim Toxins incl Trop Dis. 2014 Feb 11;20(1):3.

47. de Paula Santos-da-Silva A, Candido DM, Nencioni ALA, Kimura LF, Prezotto-Neto JP, Barbaro KC, Chalkidis HM, Dorce VAC. Some pharmacological effects of Tityus obscurus venom in rats and mice. Toxicon. 2017 Feb;126:51-8. doi: 10.1016/j.toxicon.2016.12.008.

48. Guerrero-Vargas JA, Mourão CBF, Quintero-Hernández V, Possani LD, Schwartz EF. Identification and phylogenetic analysis of Tityus pachyurus and Tityus obscurus novel putative $\mathrm{Na}^{+}$channel scorpion toxins. PLoS ONE. 2012;7(2):e30478.

49. Page MJ, Moher D, Bossuyt PM, Boutron I, Hoffmann TC, Mulrow CD, Shamseer L, Tetzlaff JM, Akl EA, Brennan SE, Chou R, Glanville J, Grimshaw JM, Hróbjartsson A, Lalu MM, Li T, Loder EW, Mayo-Wilson E, McDonald S, McGuinness LA, Stewart LA, Thomas J, Tricco AC, Welch VA, Whiting P, McKenzie JE. PRISMA 2020 explanation and elaboration: updated guidance and exemplars for reporting systematic reviews. BMJ. 2021 Mar 29;372:n160. doi: 10.1136/bmj.n160.

50. Floch $\mathrm{H}$, Barrat R, Abonnec E. L'envenimation par piqure de scorpions en Guyane Francaise. Institute Pasteur de la Guyane et du Territoire de I'Inini. 1950;219:1-4.

51. Pardal PPO, Castro LC, Jennings E, Pardal JSO, Monteiro MRCC. Aspectos epidemiológicos e clínicos do escorpionismo na regiao de Santarém, Estado do Pará, Brasil. Rev Soc Bras Med Trop. 2003 May-Jun;36(3):349-53.

52. Pardal PPO, Gadelha MAC, Ortiz Meneses MMG, Malheiros RS, Ishikawa EAY, Gabriel MDG. Envenenamento grave pelo escorpião Tityus obscurus Gervais, 1843. Rev Panamazonica Saude. 2014 Set;5(3):65-70.

53. Torrez PPQ, Quiroga MMM, Abati PAM, Mascheretti M, Costa WS, Campos LP, França FOS. Acute cerebellar dysfunction with neuromuscular manifestations after scorpionism presumably caused by Tityus obscurus in Santarém, Pará / Brazil. Toxicon. 2015 Mar;96:68-73.

54. Lourenço WR, Ythier E. Description of Tityus (Atreus) cisandinus sp. $\mathrm{n}$. from Ecuadorian Amazonia, with comments on some related species (Scorpiones: Buthidae). Riv Aracnol Ital. 2017;15:18-34.
55. Khattabi A, Soulaymani-Bencheikh R, Achour S, Salmi LR, Scorpion Consensus Expert Group. Classification of clinical consequences of scorpion stings: consensus development. Trans R Soc Trop Med Hyg. 2011 Jul;105(7):364-9.

56. Bucaretchi F, Fernandes LCR, Fernandes CB, Branco MM, Prado CC, Vieira RJ, De Capitani EM, Hyslop S. Clinical consequences of Tityus bahiensis and Tityus serrulatus scorpion stings in the region of Campinas, southeastern Brazil. Toxicon. 2014 Oct;89:17-25.

57. de Roodt AR, García SI, Salomón OD, Segre L, Dolab JA, Funes RF, de Titto $\mathrm{H}$. Epidemiological and clinical aspects of scorpionism by Tityus trivittatus in Argentina. Toxicon. 2003 Jun;41(8):971-7. doi: 10.1016/ s0041-0101(03)00066-7.

58. Mazzei de Dávila CA, Dávila DF, Donis JH, de Bellabarba GA, Villarreal V, Barboza JS. Sympathetic nervous system activation, antivenin administration and cardiovascular manifestations of scorpion envenomation. Toxicon. 2002 Sep;40(9):1339-46.

59. Gómez JP, Quintana JC, Arbeláez P, Fernández J, Silva JF, Barona J, Gutiérrez JC, Díaz A, Otero R. Picaduras por escorpión Tityus asthenes en Mutatá, Colombia: aspectos epidemiológicos, clínicos y toxinológicos. Biomedica. 2010;30(1):126-39.

60. Izquierdo LM, Rodríguez Buitrago JR. Cardiovascular dysfunction and pulmonary edema secondary to severe envenoming by Tityus pachyurus sting. Case report. Toxicon. 2012 Sep 15;60(4):603-6.

61. Daisley H, Alexander D, Pitt-Miller P. Acute myocarditis following Tityus trinitatis evenoming: morphological and pathophysiological characteristics. Toxicon. 1999 Jan;37(1):159 - 65.

62. Hernández Lomelí A, Ríos Osronio I, Cardona Cabrera R. Prevalencia de la picadura de alacrán en la ciudad de Querétaro. Rev Med IMSS. 1994 Nov-Dec;32(6):527-31.

63. Montoya-Cabrera M. Alacranismo. Gac Med Mex. 1996 NovDec;132(6):645-8.

64. Bergman NJ. Clinical description of Parabuthus transvaalicus scorpionism in Zimbabwe. Toxicon. 1997 May;35(5):759-71.

65. Fuchs S, Goyffon M, Perrigot M. Neurogenic bladder dysfunction after scorpion sting. Toxicon. 1998;36(12):1728-9.

66. Sofer S, Gueron M. Vasodilators and hypertensive encephalopathy following scorpion envenomation in children. Chest 1990 Jan;97(1):118-20.

67. Bahloul M, Rekik N, Chabchoub I, Chaari A, Ksibi H, Kallel H, Damak H, Chaari A, Ben Hamida C, Chelly H, Bouaziz M. Neurological complications secondary to severe scorpion envenomation. Med Sci Monit. 2005 Apr;11(4):CR196-202.

68. Clot-Faybesse $\mathrm{O}$, Guieu R, Rochat H, Devaux C. Toxicity during early development of the mouse nervous system of a scorpion neurotoxin active on sodium channels. Life Sci. 2000;66(3):185-92. doi: 10.1016/ s0024-3205(99)00579-2.

69. Ismail M, Kertesz G, Osman OH, Sidra MS. Distribution of $125 \mathrm{I}$ labelled scorpion (Leiurus quinquestriatus $\mathrm{H} \& \mathrm{E}$ ) venom in rat tissues. Toxicon. 1974 Mar;12(2):209-11.

70. Leipold E, Hansel A, Borges A, Heinemann SH. Subtype specificity of scorpion beta-toxin Tz1 interaction with voltage-gated sodium channels is determined by the pore loop of domain 3. Mol Pharmacol. 2006 Jul;70(1):340-7. doi: 10.1124/mol.106.024034.

71. Waxman SG, Dib-Hajj S, Cummins TR, BlackJA. Sodium channels and their genes: dynamic expression in the normal nervous system, dysregulation in disease states ${ }^{1}$ Brain Res. 2000 Dec 15;886(1-2):5-14. doi: 10.1016/ s0006-8993(00)02774-8.

72. Gilles N, Chen H, Wilson H, Le Gall F, Montoya G, Molgo J, Schönherr R, Nicholson G, Heinemann SH, Gordon D. Scorpion a and a-like toxins differentially interact with sodium channels in mammalian CNS and periphery. Eur J Neurosci. 2000 Aug;12(8):2823-32.

73. Bushart DD, Shakkottai VG. Ion channel dysfunction in cerebellar ataxia. Neurosci Lett. 2019 Jan 1;688:41-8. doi: 10.1016/j.neulet.2018.02.005.

74. Du X, Carvalho-de-Souza JL, Wei C, Carrasquel-Ursulaez W, Lorenzo Y, Gonzalez N, Kubota T, Staisch J, Hain T, Petrossian N, Xu M, Latorre R, Bezanilla F, Gomez CM. Loss-of-function BK channel mutation causes impaired mitochondria and progressive cerebellar ataxia. Proc Natl Acad Sci U S A. 2020 Mar 17;117(11):6023-34. 
75. Abroug F, Ouanes-Besbes L, Tilouche N, Elatrous S. Scorpion envenomation: state of the art. Intensive Care Med. 2020 Mar;46(3):40110. doi: 10.1007/s00134-020-05924-8.

76. Petricevich VL. Scorpion venom and the inflammatory response. Mediators Inflamm. 2010;2010: 903295

77. Rodríguez de la Vega RC, Possani LD. Overview of scorpion toxins specific for $\mathrm{Na}+$ channels and related peptides: biodiversity, structure-function relationships and evolution. Toxicon. 2005;46(8):831-44. doi: 10.1016/j. toxicon.2005.09.006.

78. Abdel-Haleem AHA, Meki ARMA, Noaman HA, Mohamed ZT. Serum levels of IL- 6 and its soluble receptor, TNF- $a$ and chemokine RANTES in scorpion envenomed children: their relation to scorpion envenomation outcome. Toxicon. 2006 Mar 15;47(4):437-44.

79. Chtara K, Bahloul M, Turki O, Baccouche N, Regaieg K, Ben Hamida C, Chelly H, Chabchoub I, Chaari A, Bouaziz M. Incidence and impact outcome of hyperglycaemia in severe scorpion envenomed children requiring intensive care admission. Intensive Care Med. 2015 Out;41(10):1871-2.

80. Ruiming Z, Yibao M, Yawen H, Zhiyong D, Yingliang W, Zhijian C, Wenxin L. Comparative venom gland transcriptome analysis of the scorpion Lychas mucronatus reveals intraspecific toxic gene diversity and new venomous components. BMC Genomics. 2010 jul 28;11:452.

81. Ceccarelli FS, Ojanguren-Affilastro AA, Ramírez MJ, Ochoa JA, Mattoni Cl, Prendini L. Andean uplift drives diversification of the bothriurid scorpion genus Brachistosternus. J Biogeography. 2016 May 13;43(10):1942-54.

82. Fet $\mathrm{V}$, Kovařík F, Gantenbein B, Kaiser RC, Graham MR, Stewart AK. Revision of the Mesobuthus caucasicus complex from Central Asia, with descriptions of six new species (Scorpiones: Buthidae). Euscorpius. 2018;(255):1-77.

83. Borja-Oliveira CR, Pertinhez TA, Rodrigues-Simioni L, Spisni A. Positive inotropic effects of Tityus cambridgei and T. serrulatus scorpion venoms on skeletal muscle. Comp Biochem Physiol C Toxicol Pharmacol. 2009 Apr;149(3):404-8.

84. Batista CVF, Zamudio FZ, Lucas S, Fox JW, Frau A, Prestipino G, Possani LD. Scorpion toxins from Tityus cambridgei that affect $\mathrm{Na}^{+}$-channels. Toxicon. 2002 May;40(5):557-62.

85. Batista CVF, del Pozo L, Zamudio FZ, Contreras S, Becerril B, Wanke E, Possani LD. Proteomics of the venom from the amazonian scorpion Tityus cambridgei and the role of prolines on mass spectrometry analysis of toxins. J Chromatogr B Analyt Technol Biomed Life Sci. 2004 Apr 15;803(1):55-66.

86. Batista CVF, Gómez-Lagunas F, Lucas S, Possani LD. Tc1, from Tityus cambridgei, is the first member of a new subfamily of scorpion toxin that blocks K+-channels. FEBS Lett. 2000 dec 8;486(2):117-20.

87. Batista CVF, Gómez-Lagunas F, Rodruíguez de la Vega RC, Hajdu P, Panyi Gr, Gáspár R, Possani LD. Two novel toxins from the Amazonian scorpion Tityus cambridgei that block Kv1.3 and Shaker B K+ -channels with distinctly different affinities. Biochim Biophys Acta Proteins Proteom. 2002 Dec 16;1601(2):123-31.

88. de Oliveira UC, Nishiyama Jr MY, Dos Santos MBV, Santos-da-Silva AP, Chalkidis HM, Souza-Imberg A, Candido DM, Yamanouye N, Dorce VAC, Junqueira-de-Azevedo ILM. Proteomic endorsed transcriptomic profiles of venom glands from Tityus obscurus and T. serrulatus scorpions. PLoS One. 2018 Mar 21;13(3):e0193739.

89. Carvalho DC, Kuniyoshi AK, Kodama RT, Oliveira AK, Serrano SMT, Tambourgi DV, Portaro FV. Neuropeptide Y family-degrading metallopeptidases in the Tityus serrulatus venom partially blocked by commercial antivenoms. Toxicol Sci. 2014 Dec;142(2):418-26.

90. Dias NB, de Souza BM, Cocchi FK, Chalkidis HM, Dorce VAC, Palma MS. Profiling the short, linear, non-disulfide bond-containing peptidome from the venom of the scorpion Tityus obscurus. J Proteomics. 2018 Jan 6;170:70-9. doi: 10.1016/j.jprot.2017.09.006.
91. Almaaytah A, Albalas Q. Scorpion venom peptides with no disulfide bridges: a review. Peptides. 2014 Jan;51:35-45. doi: 10.1016/j.peptides.2013.10.021.

92. Veloso Júnior PHH, Simon KS, de Castro RJA, Coelho LC, Erazo FAH, de Souza ACB, das Neves RC, Lozano VF, Schwartz EF, Tavares AH, Mortari MR, Junqueira-Kipnis AP, Silva-Pereira I, Bocca AL. Peptides ToAP3 and ToAP4 decrease release of inflammatory cytokines through TLR-4 blocking. Biomed Pharmacother. 2019 Oct;118:109152. doi: 10.1016/j.biopha.2019.109152.

93. Mourão CBF, Brand GD, Fernandes JPC, Prates MV, Bloch Jr C, Barbosa JARG, Freitas SM, Restano-Cassulini R, Possani LD, Schwartz EF. Headto-tail cyclization after interaction with trypsin: a scorpion venom peptide that resembles plant cyclotides. J Med Chem. 2020 Sep 10;63(17):9500-11. doi: 10.1021/acs.jmedchem.0c00686.

94. Duque HM, Mourão CBF, Tibery DV, Barbosa EA, Campos LA, Schwartz EF. To4, the first Tityus obscurus $\beta$-toxin fully electrophysiologically characterized on human sodium channel isoforms. Peptides. 2017 Sep;95:106-15. doi: 10.1016/j.peptides.2017.07.010.

95. Tibery DV, Campos LA, Mourão CBF, Peigneur S, e Carvalho AC, Tytgat J, Schwartz EF. Electrophysiological characterization of Tityus obscurus $\beta$ toxin 1 (To1) on $\mathrm{Na}^{+}$-channel isoforms. Biochim Biophys Acta Biomembr. 2019 Jan;1861(1):142-50. doi: 10.1016/j.bbamem.2018.08.005

96. Schaller KL, Caldwell JH. Expression and distribution of voltage-gated sodium channels in the cerebellum. Cerebellum. 2003;2(1):2-9. doi: 10.1080/14734220309424.

97. Vasconcelos F, Lanchote VL, Bendhack LM, Giglio JR, Sampaio SV, Arantes EC. Effects of voltage-gated $\mathrm{Na}^{+}$channel toxins from Tityus serrulatus venom on rat arterial blood pressure and plasma catecholamines. Comp Biochem Physiol. 2005 May;141(1):85-92.

98. Murgia AR, Batista CVF, Prestipino G, Possani LD. Amino acid sequence and function of a new a-toxin from the amazonian scorpion Tityus cambridgei. Toxicon. 2004 May;43(6):737-40.

99. Wang I, Wu SH, Chang HK, Shieh RC, Yu HM, Chen C. Solution structure of a $\mathrm{K}^{+}$-channel blocker from the scorpion Tityus cambridgei. Protein Sci. 2002 Feb;11(2):390-400.

100. Bergeron ZL, Bingham JP. Scorpion toxins specific for potassium $\left(\mathrm{K}^{+}\right)$ channels: a historical overview of peptide bioengineering. Toxins (Basel). 2012 Nov 1;4(11):1082-119.

101. Batista CVF, Martins JG, Restano-Cassulini R, Coronas FIV, Zamudio FZ, Procópio R, Possani LD. Venom characterization of the amazonian scorpion Tityus metuendus. Toxicon. 2018 Mar 1;143:51-8. doi: 10.1016/j. toxicon.2018.01.006.

102. De Rezende NA, Dias MB, Campolina D, Chavez-Olortegui C, Diniz $\mathrm{CR}$, Amaral CF. Efficacy of antivenom therapy for neutralizing circulating venom antigens in patients stung by Tityus serrulatus scorpions. Am J Trop Med Hyg. 1995 Mar;52(3):277-80.

103. Guerra-Duarte C, Rebello Horta CC, Ribeiro Oliveira-Mendes BB, de Freitas Magalhães B, Costal-Oliveira F, Stransky S, Fonseca de Freitas C, Campolina D, Pardal PPO, Lira-da-Silva R, Machado de Ávila RA, Kalapothakis E, Chávez-Olórtegui $C$. Determination of hyaluronidase activity in Tityus spp. Scorpion venoms and its inhibition by brazilian antivenoms. Toxicon. 2019 Sep;167:134-43.

104. Guerra-Duarte C, Alvarenga LM, Dias-Lopes C, Machado-de-Ávila RA, Nguyen C, Molina F, Granier C, Chávez-Olórtegui C. In vivo protection against Tityus serrulatus scorpion venom by antibodies raised against a discontinuous synthetic epitope. Vaccine. 2010 Feb 3;28(5):1168-76. doi: 10.1016/j.vaccine.2009.11.039.

105. Molina Molina DA, Guerra-Duarte C, Costal-Oliveira F, Almeida Rocha E, Rego Rodrigues C, Machado-de-Ávila RA, Soccol VT, Chávez-Olórtegui $\mathrm{C}$. Engineered protein containing crotoxin epitopes induces neutralizing antibodies in immunized rabbits. Mol Immunol. 2020 Mar;119:144-53. doi: 10.1016/j.molimm.2020.01.012. 